\title{
Marketing Privacy
}

\author{
Ian Ayres ${ }^{\dagger}$ \\ Matthew Funk ${ }^{\dagger \dagger}$
}

Unsolicited solicitations in the form of telemarketing calls, email spam and junk mail impose in aggregate a substantial negative externality on society. Telemarketers do not bear the full costs of their marketing because they do not compensate recipients for the hassle of, say, being interrupted during dinner. Current regulatory responses that give consumers the all-or-nothing option of registering on the Internet to block all unsolicited telemarketing calls are needlessly both over-and underinclusive. A better solution is to allow individual consumers to choose the price per minute they would like to receive as compensation for listening to telemarketing calls. Such a "name your own price" mechanism could be easily implemented technologically by crediting consumers' phone bills (a method analogous to the current debits to bills from $1-900$ calls). Compensated calling is also easily implemented within current "don'tcall" statutes simply by giving "don't-call" households the option to authorize intermediaries to connect calls that meet their particular manner or compensation prerequisites.

Under this rule, consumers are presumptively made better off by a regime that gives them greater freedom. Telemarketing firms facing higher costs of communication are likely to better screen potential contacts. Consumers having the option of choosing an intermediate price will receive fewer calls, which will be better tailored to their interests, and will be compensated for those calls they do receive.

Giving consumers the right to be compensated may also benefit some telemarketers. Once consumers are voluntarily opting to receive telemarketing calls (in return for tailored compensation), it becomes possible to deregulate the telemarketers-lifting current restrictions on the time (no night time calls) and manner (no recorded calls). And faced with increasing caller resistance, we imagine that survey groups, such as the Gallop Poll, might welcome the opportunity to compensate survey respondents so that they might be able to produce more representative samples.

$\dagger \quad$ Townsend Professor, Yale Law School.

†† Matthew Funk is an attomey at Sımpson, Thacher \& Bartlett and a research associate at Dartmouth College's Institute for Security Technology Studies. Michael Abramowicz, Anıta Allen, Russ Atkınd, Jennifer Brown, Lloyd Cohen, Ken Eichenbaum, Peter Siegelman, Jim Sorce, Phil Spector, Cass Sunstein, Nasser Zakanaya and participants at George Mason Law School and FTC, Bureau of Economics seminars provided helpful comments.

Copyright $\odot 2003$ by Yale Journal on Regulation 


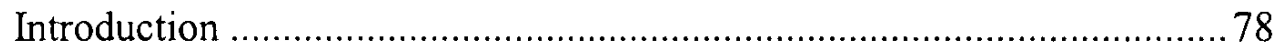

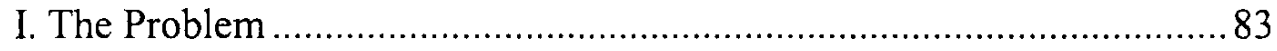

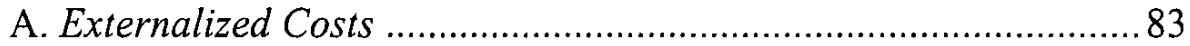

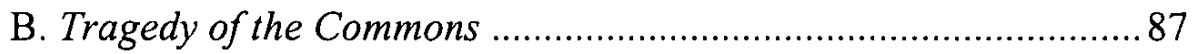

C. Current Legislative Responses ......................................................93

II. The Market Solution ..................................................................

A. Comparison with Improved Initial Disclosure............................. 102

B. Comparison with Private and Public Interdiction ....................... 104

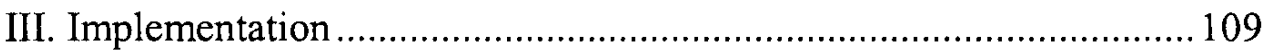

A. Our Preferred Approach-Authorized

Intermediation .................................................................... 110

B. The Pricing Mechanism ............................................................ 113

1. Who Should Offer the Price................................................113

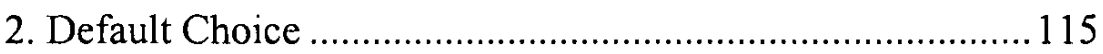

C. Exempt Solicitations ................................................................117

1. Positive Externalities: Charities, Polling and

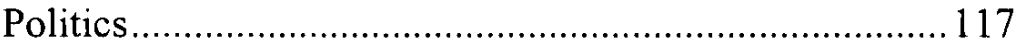

2. Policing "Consumer Consent" ........................................... 122

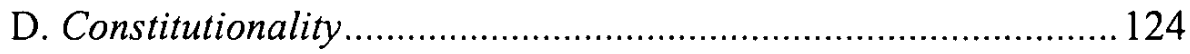

IV. Theoretical Critiques of Privacy Markets........................................... 127

A. Sunstein's Concern With Excessive Filtering ……….................. 128

B. Radin's Concern with Commodification ......................................130

C. Allen's Concern with Uncoerced Privacy ...................................132

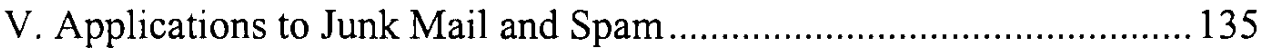

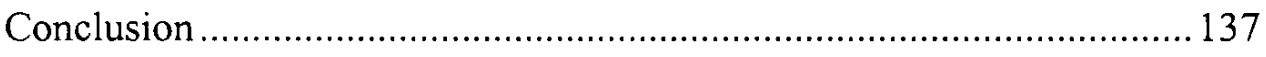

"[T]he right of every person 'to be let alone' must be placed in the scales with the right of others to communicate."

Rowan v. Post Office Department, 397 U.S. 728, 736 (1970).

Introduction

The billions of telemarketing calls that individuals endure each year are in aggregate a substantial invasion of residential privacy. ${ }^{1}$ Who has not been interrupted at the dinner table by an unwanted call pitching storm windows or mortgage refinancing? We all have stories of particularly outrageous or obnoxious calls. ${ }^{2}$ Virtually no one likes the current system.

1 A discussion of the number of telemarketing calls can be found infra note 28 and accompanying text

2 See, e.g., John Greenwald, Sorry, Right Number, TIME, Sept. 13, 1993, at 66 (relatıng the story of a doctor being called away from a patient in a trauma center by a telemarketer); Don 
Telemarketing ranked fourth among the 100 worst ideas of the 20 th century in a poll by Time magazine. ${ }^{3}$ In short, we all know telemarketing calls are a major pain. What goes unnoticed, however, is that these unwanted intrusions may represent the most frequent and substantial intrusion on people's fundamental right to be left alone in their homes.

Telemarketers don't bear the full costs of their marketing because they do not compensate recipients for the hassle of, say, being interrupted during dinner. Telemarketers bear the cost of their speaking, but not of residents' listening. ${ }^{4}$ It can still be privately rational for a telemarketer to disturb thirty people, if he or she can succeed in making a high-profit sale to the thirty-first. Because of these externalized costs, telemarketers have an incentive to call too often. The traditional laissez-faire approach has perversely created a public commons in an important, personal sphere of domestic privacy - the residential telephone lines that literally reach into the most intimate spaces and moments of our lives.

The current legislative movement to combat this telemarketing abuse-promoting "don't-call" statutes-forces residents to make an unreasonable, all-or-nothing choice: either they register on the state's "don't-call" list and thereby opt out of all for-profit telemarketing calls or they remain subject to potentially unlimited telemarketing harassment. "Don't-call" statutes have already been passed by twenty states and are in the works in four more. ${ }^{5}$ Moreover, the FTC has just proposed promulgating a national "don't-call" registry that would give every U.S. citizen this all-or-nothing choice.

While the "don't-call" registries are improvements over the status quo, they are unnecessarily over- and under-inclusive. Many of the

Oldenburg, Anti-Telemarketers Send Out a Very Busy Signal, WASH. POST, Feb. 20, 2002, at C1 (describing how telemarketers interrupted "a multumillion-dollar international deal in 1994 to feed starving children in Bosnia").

3 Ben Finley, Federal Do-Not-Call List Weighed by Agencies, PITT. POST-GazetTe, Sept. 22,2002 , at $\mathrm{A} 3$.

4 This point about cost externalization is powerfully made in an excellent article by Ross Petty that repays close reading. Ross D. Petty, Marketing Without Consent: Consumer Choice and Costs, Privacy and Public Policy, 19 J. PUB. POL'Y \& MARKETING 42 (2000).

5 See AlaSka STAT. \$ 45.50 .475 (Michıe 2001); ARK. CODE ANN. § 4-99-404 (Michıe 2001); Cal. Bus. \& Prof. COde $\$ 17592$ (West 2002); Colo. Rev. Stat. ANN. $\$ 6-1-905$ (West 2001); CONN. GEN. STAT. ANN. § 42-288a (West Supp. 2002); Fla. STAT. ANN. § 501.059 (West 2001); GA. CODE ANN. § 46-5-27 (2001); IDAHO CODE § 48-1003A (Michie 2001); IND. CODE ANN. $\S$ 24-4.7-1 (West 2001); KY. REV. STAT. ANN. § 367.46955 (Banks-Baldwn 2001); LA. REV. STAT. ANN. \$ 45:844.14 (West 2002); ME. REV. STAT. ANN. tit. 32, § 14716 (West 2001); MO. ANN. STAT. $\S 407.1098$ (West 2001); N.Y. GEN. BUS. LAW \$399-z (McKinney 2002); OR. REV. STAT. \$ 646.569 (2001); TENN. CODE ANN. \$65-4-405 (2001); TEX. BUS. \& COM. CODE ANN. $\$ 43.101$ (Vernon 2001); WIS. STAT. $\$ 100.52$ (2001); WYO. STAT. ANN. $\S 40-12-302$ (Michie 2001); STATE OF Alabama Public SERVICE COMMISSION, TElePhONe RUles (1992), available at http://www.psc.state.al.us/_Admınıstrative/Revtelephonerulesoct6.pdf. As of October 200l, "no call" list legislation was pending in Michigan, New Jersey, Pennsylvania, and Ohio. See Diana Mey, State Telemarketıng Laws, at http://www.dianamey.com/State_telem_laws.html (last modified Oct. 2001).

6 Oldenburg, supra note 2 (as of the final editing of this Artıcie). 
residents who opt for "don't-call" status receive too few calls compared to what they would want if they were compensated; similarly, many of the residents that fail to register receive too many calls relative to what they would prefer if the telemarketers had to compensate them.

This Article proposes to expand residents' choices. Households should be allowed to decide how much they will be compensated for receiving telemarketing calls. ${ }^{7}$ It is technologically feasible to give households the ability to determine how much they will be compensated per minute for listening to a telephone pitch. This approach would still give households the "don't-call" options of banning all telemarketing calls (in effect setting an infinite price) or allowing any call by setting a zero price.

But many consumers will choose intermediate amounts. Telemarketing, like other forms of advertising, can provide useful information to potential consumers. And telemarketers who have to compensate consumers have greater incentives to screen their call lists to focus their calling on consumers who are more likely to be interested in the information.

The result is a boon to consumers. On simple libertarian grounds, consumers are presumptively made better off by a regime that gives them greater freedom. More concretely, consumers will (1) receive fewer calls, (2) which will be more tailored to their interests and (3) be compensated (with amounts that they themselves have indicated are sufficient) for those calls they do receive.

This "name your own price" system may also benefit some telemarketers-even though they have to start compensating listeners. For some firms, our system would represent an increase in telemarketing freedom. Instead of being prohibited from calling people on the "don'tcall" list, telemarketers could call anyone-as long as they were willing to pay the person's (potentially infinite) price. Even without the "don't-call" statutes, many people have privately opted out of the pools by making their numbers unlisted or by immediately hanging up on all such calls. Indeed, it has become something of a national pastime for consumers to devise new ways to detect and terminate telemarketing intrusions. But this current rush to judgment also prevents socially beneficial solicitations from being heard. Giving telemarketers the option of compensating consumers represents a new way for the most beneficial parts of the telemarketing industry to overcome consumer resistance. For example, we imagine that the Gallup Organization might welcome the opportunity to compensate survey respondents so that the polling firm could produce more representative samples.

7 We filed a provisional patent application for a "name your own price" telemarketing mechanism on October 3,2000. But we hereby renounce and waive any financial interest in the intellectual property. We hope to make the idea as free as the air. 
Our system might also benefit telemarketers by making it possible to deregulate other aspects of the telemarketing industry. Federal law currently prohibits telemarketers from calling between 9 p.m. and 8 a.m. or from faxing solicitations, ${ }^{8}$ and many states prohibit tape-recorded solicitations. ${ }^{9}$ These laws make eminent sense in a world where consumers are not compensated. But in a world with consumer consent-in which consumers volunteer (for compensation) to listen to telemarketing solicitations-there is no longer a reason for such per se prohibitions. As a technological matter, there is no reason why consumers couldn't set different prices for different times of day or different types of solicitations. If the prohibition against tape-recorded messages were repealed, we could imagine local grocery stores or movie theaters using the telephone to provide consumers with useful information about specials. These telemarketers would have to pay the listeners, but with tape-recordings they would dramatically reduce the costs of speaking.

Make no mistake. We predict that some types of telemarketing calls would be driven into the dust bin of history by a system of mandated compensation. And a good thing too. Many telemarketing calls are not cost-justified when one takes into account the real costs of listening. Telemarketers under the current system don't take into account the annoyance of the 50 consumers who fail to buy when they are trolling for the consumer who will bite. And perversely, the new "don't-call" laws exacerbate the overfishing problem as telemarketers concentrate their attention on those consumers who fail to register. The likely result of this phenomenon is an inefficient unraveling with too little telemarketing for those who register and too much for those who fail to register.

The technology for such a compensated-telemarketing system is no more complicated than that for existing 1-900 numbers. Under our preferred scheme, the telemarketers would be required to call from an "outgoing 1-900 number." With existing 1-900 numbers, a payment from the caller to the recipient is triggered when the caller dials into a 1-900 number. But with an outgoing 1-900 number, transfers based on a perminute fee set by consumers would be made from the telemarketer to the consumer's telephone bill when the telemarketer calls out from a 1-900 number.

A system of compensated telemarketing can easily be accommodated within the FTC's current "don't-call" proposal. The current proposal allows telemarketers to call people who have registered for "don't-call" status if the household has given an "express authorization" to a "specific

8 See FTC Restriction on Telephone Solicitations, 47 C.F.R. $\S 64.1200(e)(1)(2002)$.

9 See, e.g., CONN. GEN. STAT. ANN. § 42-288a(c)(4) (West Supp. 2002); see also Telephone Consumer Protection Act of 1991, 47 U.S.C.A. $\$ 227$ (b)(1)(B) (West 2001) (prohıbıtıng initiatıng solıcitations with a pre-recorded message). 
seller." ${ }^{\prime 10}$ But by adding about two dozen words to the proposed regulation, it is possible to expand the concept of express authorization to include intermediaries, such as Verizon or Sprint, who would connect the call. A household that registers for the "don't-call" list with this slight amendment could simultaneously empower a local phone company or a long distance carrier to connect telemarketing calls that meet the household's compensation prerequisites.

This concept of "authorized intermediation" radically simplifies the government's regulatory burden because it privatizes a substantial bulk of the compensated calling system. An intermediary market works out the issues of tailoring the compensation system to household demand. Instead of registering the price you want to receive with the FTC, you would register the price (or prices for different times of day or different types of calls) you want to receive with the intermediary. The government can avoid difficult questions of default setting and content-based regulation by leaving it to a competitive intermediation market to provide the types of compensation schemes that households want. Moreover, the intermediary approach allows the individual household to deregulate the current per se prohibitions on direct marketing. So long as the sender pays the household's compensation requirements, the intermediary is authorized to connect telemarketing faxes, cell-phone calls, nighttime calls, or prerecorded calls.

This Article is divided into five parts. First, we address the problems of externalized costs created by the current laissez-faire regime governing solicitation. Part II provides the affirmative case for creating a market in the right to be left alone. This Section shows how the idea of compensated solicitation solves the externalized cost problem of direct marketing and explains the superiority of a market approach to alternative regimes. Part III then goes on to discuss the details of implementation. Here, we take on both legal and practical challenges to making our mechanism work. Part IV responds to a series of theoretical critiques of markets found in the writings of Anita Allen, Margaret Radin and Cass Sunstein. Finally, Part V considers practical implementation issues of how this "name your own price" solution could be analogously used to mitigate the problems of spam and junk mail.

10 Telemarketıng Sales Rule, $\$ 310.4(b)(1)(i 11), 67$ Fed. Reg, 4492-01 (proposed Jan. 30, 2002) (to be codıfied at 16 C.F.R. pt. 310), available at http://www.ftc.gov/bcp/conlıne/edcams/ donotcall/pubs/NDNCR_therule.pdf [hereınafter Telemarketıng Sales Rule]. 
Marketing Privacy

\section{THE PROBLEM}

\section{A. Externalized Costs}

Consumers, legislators and academics typically regard most kinds of direct marketing-unsolicited solicitations arriving by telephone, mail or the Internet-as a nuisance. Legal scholars at least will recognize that this view makes sense given the formal as well as the colloquial meanings of the term-many direct marketing solicitations are not only irritating, they are also more burdensome to the recipient than beneficial to the sender. Parties that view solicitations as a nuisance naturally focus on developing methods for blocking it."

As emphasized above, this is a nuisance of a particularly important character. While many of us have gradually become inured to the unpleasant reality of telemarketing calls, it is useful to remember that this nuisance implicates the most basic sort of privacy - the right to be left alone in one's home.

The unwanted solicitation intrudes in two distinct ways. The intrusion is not only in the time spent talking on the phone (or in extracting yourself from the conversation). But it is also in hearing the phone ring and literally moving your body across the room to pick it up. Thus, even if the modern desensitized human can bring herself to quickly terminate the call, there is the substantial disruption of just the pick up itself.

Unlike other nuisances that need only seep across our property lines to be actionable, the telemarketing nuisance intrudes literally into the most

11 This connection between parties' interpretation of the problem and the solution is especially visible in regard to spam. Email advertising has many virtues: it costs virtually nothing to create and dissemınate; it is instantaneous, environmentally friendly, and relatively unıntrusive; and it places reciprents just a click away from the point-of-sale. Yet well-known Internet personalıties and the online community as a whole deride spam as a "time- and money-wasting mess" and regard its usage as a violation of onlıne norms. Anne E. Hawley, Taking Spam Out of Your Cyberspace Diet. Common Law Applied to Bulk Unsolicited Advertising via Electronic Mail, 66 UMKC L. Rev. 381, 382 n.11 (1997) (quotıng Ried Kanaley, Sorting Out the Spam Issues Behind Stopping Junk Email, BUFF. NEwS, Aug. 5, 1997, at D7). Unsurprisingly, therefore, Internet Service Providers (ISPs) have generally sought to deal with spam by installing filters that exclude it from users' inboxes. Groups of programmers, meanwhile, have created devices such as the Open Relay Blocking System and the MAPS Realtıme Blackhole List that block not merely individual pieces of spam but all email from servers that host spammers or relay their advertisements. See Lawrence Lessig, The Spam Wars, THE INDUS. STANDARD, Dec. 31, 1998, available at http://www.thestandard.com/ article $/ 0,1902,3006,00 \mathrm{html}$. Although there is no federal law goverming spam, several legislative initiatıves are currently underway to allow recipients to "opt-out" of receiving junk email. See, e.g., CAN Spam Act of 2001, S.630, 107th Cong. (2001) (requirng senders of unsolicited commercial emails to have a valıd return address so that consumers can request removal from the malling list). State legislation is also pending, though the movement to restrict spam seems to have lost steam in recent years. See, e.g., H.R. 4581, 181 st Gen. Ct., Reg. Sess. (Mass. 1997) (limitıng commercial email solicitations to those with whom a sender has a pre-existing business relatıonship). Because they view spam as a nuisance, these parties have fought to keep it off the Internet. 
intimate parts of our homes-our bedrooms, our kitchens, our living rooms - because these are the very places where we want telephones to give us ready access to our friends and family and solicited contacts with the marketplace. Unwanted direct solicitations expose us not only to unsolicited calls about magazine subscriptions and travel packages, and unsolicited letters asking us to refinance our homes and pitching new credit cards, but increasingly to unsolicited spam emails advertising getrich-quick schemes and hardcore pornography.

The social displeasure caused by direct solicitations is hardly newsworthy. But the root cause of the problem often goes unnoticed. The core problem is one of externalized costs. ${ }^{12}$ We reflexively think of direct marketing as a pariah injury. Literally our first response is to think there ought to be a law banning it. But direct marketing is not malum in se. There are real benefits to both buyers and sellers from allowing retailers (and others) to provide information. Indeed, the real benefits of direct markets are related to the benefits of a free and robust marketplace of ideas. No, the reason why direct marketing is frequently a nuisance (in the formal sense of the term) is that the legal regime does not compel direct marketers to internalize the full costs of their activities.

Direct marketing imposes costs not merely on the businesses that speak, but also on the consumers who listen. ${ }^{13}$ And though it is hard to quantify the cost of sorting through the advertisements that accumulate in one's inbox during a vacation, these kinds of intrusions provoke strong emotions among consumers. For example, the first large-scale use of spam-by a pair of attorneys, no less-provoked so many angry responses (or "flames") that the replies overloaded the spammers' ISP, provoking a temporary shutdown. ${ }^{14}$ Most consumers' frustration with spam, moreover, pales compared to their exasperation when they receive a telemarketing call during dinner. ${ }^{15}$

12 See Petty, supra note 4.

13 Spammers also externalize the costs of transmitting their solicitations. Spammers do not even reımburse ISPs for the costs of transmitting email advertısements. These costs can be substantial. ISPs report that nearly two dollars of each customer's monthly bill is attributable to spam. See Daniel P. Dern, Postage Due on Junk E-mail-Spam Costs Internet Millions Every Month, INTERNET WEEK, May 4, 1998, at T1, available at http://www.techweb.com/se/directlınk.cgl (last visited Apr. 8, 2001). $13(1996)$

14 See Susan B. Ross, Netiquette: Etiquette Over the ABN and the Internet, 33 ARIZ. ATT'Y

15 Numerous public opınion surveys demonstrate that most consumers resent telemarketıng. In one poll, $47 \%$ of respondents indicated that telephone solicitations are "always an intrusion," while another $32 \%$ stated these solicitations were "mostly an intrusion." Executive Summary: 1998 Privacy Concerns and Consumer Choice Survey, available at http://www.privacyexchange.org/lss/ surveys/1298execsum.html (last vistted Dec. 17, 2002), cited in Jeff Sovern, Opting In, Opting Out, or No Option at All: The Fight for Control of Personal Information, 74 WASH. L. REV. 1033, 1058 n.135 (1999). Another poll, commissioned by Pacific Telephone Company, reported that $86.9 \%$ of respondents found sales calls annoyng. Field Research Corp., The California Public's Experience with and Attıtude Toward Unsolicited Telephone Calls 9 (Mar. 1978) (unpublished report prepared for the Pacific Telephone Company, on file with the Yale Journal on Regulation), cited in Mark S. Nadel, 
Because direct marketers do not internalize the full costs of their behavior, they solicit an excessively broad audience. Direct marketers have access to considerable information about individuals' buying habits. This information allows them to assess whether a particular consumer is likely to purchase a specific product. But since direct marketers do not pay the costs they impose on consumers (and ISPs), they are less discriminating than they should be. When the publisher of a horse racing magazine solicits consumers who have not heretofore demonstrated any interest in the sport, that call or email probably is not cost-justified if the total social costs and benefits are reckoned. But if the publisher only calls or emails those persons who have wagered at OTB (Off-Track Betting) or purchased round trip tickets to Kentucky during early May, then there is a stronger likelihood that the benefits of the solicitation to the consumer and the publisher will outweigh the costs. Direct marketing is often a net social waste because the legal system does not give sellers of niche products adequate incentive to target likely customers.

The most striking manifestation of this phenomenon is the fact that a substantial number of direct marketers make no effort whatsoever to screen their lists of offerees. These merchants frequently try to sell products appropriate for a narrow subset of consumers to everyone they can mail or phone. This phenomenon is most common on the Internet, where the non-reputational cost to the seller of sending a piece of spam to an additional consumer approaches zero. Emailing everyone is cheaper than paying to distinguish the likely prospects and usually generates at least a few additional sales. ${ }^{16}$ Though the marginal cost of a solicitation is higher for telephone solicitation than spam, many telemarketers use the White Pages to compile their calling lists. ${ }^{17}$ These companies have been distributing phonebooks (electronic or otherwise) to their salespeople ever since the federal government enacted regulations that effectively

Rings of Privacy: Unsolicited Telephone Calls and the Right of Privacy, 4 YALE J. ON REG. 99, 100 \& n.8 (1986). See infra note 71 for additional survey results showing that a majority of consumers regard telemarketıng as a serious invasion of privacy. See also Raj Mehta \& Eugene Sivadas, Direct Marketing on the Internet: An Empirical Assessment of Consumer Attitudes, 9 J. DIRECT MARKETING 21 (1995).

16 See Derek D. Sımmons, Comment, No Seconds on Spam: A Legislative Prescription To Harness Unsolicited Commercial Email, 3 J. SMALL \& EMERging Bus L. 389, 392 n.4 (1999) ("Takıng into account the labor cost of paring a mass list to a smaller list of only the most likely customers, the mass emailıng without tallorıng the lıst is far less expensıve"); Simon Garfinkel, Spam King! Your Source for Spams Netwide!, WIRED, Feb. 1996, at 64, 66, available at http://www.wired.com/wired/archıve/4.02/spam.kıng.html (quotıng spammer Jeff Slaton: "It's just as cost-effective for me to send to 6 milhon emall addresses as to 1 million email addresses, so why bother being selective? In fact, prequalıfyıng a prospect is a dangerous thıng, simply because you might well miss a whole group of people out on the fringe.").

17 See Antitelemarketer.com, Methods of Antitelemarketing, at http://www.antitelemarketer.com/index $2 \mathrm{kl}$.htm (last visited Feb. 7, 2002). 
proscribed the use of automatic devices that sequentially dialed every combination of seven numbers in an area code. ${ }^{18}$

The prevalence of automatic calling devices underscores the fact that telemarketers do not internalize the negative externalities they create. ${ }^{19}$ The overwhelming majority of telemarketers use a technology called predictive dialers (or autodialers). ${ }^{20}$ These devices simultaneously dial batches of phone numbers and then route calls to salespeople when a consumer answers the phone. When too many consumers answer at once, the devices drop the surplus calls. ${ }^{21}$ Nynex (now Verizon) has reported that the company receives 600 complaints per week about hang-ups that the company attributes to predictive dialers. ${ }^{22}$ Telemarketers would be less likely to operate these devices at a rate fast enough to generate large numbers of hang-ups if they internalized the costs to consumers of rushing to answer the phone and hearing nothing but a dial tone when they pick up the receiver. ${ }^{23}$

Another indication that the current legal regime does not account for the negative externalities associated with direct marketing is the sheer volume of solicitations. While there is no definitive measure of the amount of telemarketing, all of the estimates are substantial. When it passed the Telephone Consumer Protection Act ("TCPA") in $1991,{ }^{24}$ Congress found that 30,000 telemarketing firms were making more than 6.5 billion calls per year. That would mean U.S. households were receiving 18 million calls per day. The FBI now estimates that there are 140,000 telemarketing

18 The TCPA bans telemarketıng calls without prior consent to emergency telephone lines such as poison control hothnes, patients' telephone numbers at health care facilities, pagers, cellular phones, or similar devices. It also bars auto-dialıng machınes from simultaneously engaging more than one of a business's phone lines. To the extent they are enforced, these regulations force telemarketers to use automatic dialing machınes with at least a small measure of nuance.

19 Telemarketing costs also impose congestion costs on the recipient. When telemarketers occupy a phone line, no other call can get through. While this congestion cost is of second-order concern, in aggregate the costs of delayed or missed calls can be substantial.

20 See Patricia Wen, All Those Hang-Ups Might Be a Computer Calling, Boston GLoBE, Apr. 21, 1997, at Bl.

21 See id. Bob Bulmash, founder of Private Citızen, Inc., observes that predictive dialers hang up on 5 to 40 percent of consumers, depending on how a company sets them up. Oldenburg, supra note 2. Dennis Hawkins observes that other problems with these devices are that they interfere with Caller-ID and will continue calling the same consumer unt1l he has answered the phone and been routed to a salesperson. DENNIS HAWKINS, THE ANTITELEMARKETER'S SOURCE, TIRED OF HANG UP CALLS? 1 (1999), available at http://www.antitelemarketer.bizland.com/hangupcalls.pdf (last visited Feb. 8, 2002).

22 See Wen, supra note 20.

23 Catherine Romano, Telemarketing Grows Up, 87 MGMT. REV. 31, 33 (1998) (noting that the hang-ups occur because many telemarketers set their predictive dialers at too fast a pace). Yet another imitating technique that might well disappear if telemarketers were compelled to internalize the costs they impose on consumers is the practice of leaving lengthy pitches on voicemail and answering machines. See id. at 34; Amy Wu, Leave Your Pitch After the Beep, ABCNews.Com, at http://abcnews.go.com/sections/business/DailyNews/telemarket990923.html., (last visited Feb. 8, 2002).

$24 \quad 47$ U.S.C. $\S 227(2002)$. 
pool of available targets, the telemarketers are driven to pursue the remaining opportunities more aggressively. This causes more households to drop out in an unraveling that currently resembles the death throes of an overfished estuary.

Because telemarketers bombard consumers with solicitations-often advertising products unrelated to the listener's interests-more and more consumers are determined to shut direct marketers out. ${ }^{29}$ There are at least three manifestations of consumers' growing determination to avoid being subjected to unsolicited solicitations: (1) declining response rates; ${ }^{30}$ (2) increasing popularity of products and services that block direct marketing; and (3) a tide of recent legislation aimed at curbing telemarketing and spam. ${ }^{31}$ Together, these phenomena constitute a looming crisis for the direct marketing industry.

Assessing changes in the percentage of consumers who respond favorably to sales calls is tricky but not impossible. We are not aware of any situations in which telemarketers released response rates. ${ }^{32}$ Even if data were available, it would be difficult to compare statistics from different sources because the term "response rate" is so ambiguous and it is hard to compare statistics across time because the wider adoption of measures such as "don't-call" lists and unlisted phone numbers has the perverse effect of appearing to increase the percentage of consumers who

29 A number of experts have noted or implied a causal relationship between the growth in the volume of solicitations and consumers' increasing determination to shield themselves from direct marketers. One artıcle quotes the following remark by Rudy Oettıng: "There's more volume to a household. And the more volume, the more defense mechanisms people are puttıng up." Romano, supra note 23 , at 2 . Rosenfield also writes that steep increases in call volume have been accompanied by "ever lower closure rates." Rosenfield, supra note 28 , at 14 . Note 30 , infra, quotes the relevant portion of Rosenfield's article at greater length

30 Readers may wonder how the telemarketıng industry has managed to grow dramatically while response rates have been plummeting; the answer is that new technology has dramatically reduced the cost to telemarketers of making a phone solicitation. Rosenfield, supra note 28 , at 14 , writes:

To visit a modern telemarketing center is to be dazzled by information age technology. One of the remarkable things is that you never see a phone! Huge central computers, with predictive dialing systems, do the work. The telemarketer is liberated to concentrate on selling. It's a far cry from the pioneering days of the 1960 s, when out-of-work actors dialed rotary phones in burned-out basements. . . But alas, nothing falls [sic] like success, and we always go too far-it's the American way. If one call makes money, two will make more! And 2,000 even more! And if we can drive the costs down, down, down, we drive the numbers up, up, up, and live with ever lower closure rates. Which means that the quality of the outbound telemarketıng experience, never sterling, has deteriorated over the last few years.

Tom Eisenhart, Telemarketing Takes Quantum Leap, ADVERTISING AGE'S BUS. MARKETING, Sep. 1993, at 75, provides a more detalled account of the new technologies used by contemporary telemarketers.

31 The First Amendment severely constrains the range of legal options for curbing direct ma1l. See, e.g., Consol. Edison Co. v. Pub. Serv. Comm'n, 447 U.S. 530 (1980).

32 The authors contacted researchers, journalists and direct marketing firms in an effort to obtain telemarketıng response rates. 
firms in the United States. ${ }^{25}$ If the number of calls per firm has remained constant (vis-à-vis the TCPA findings), then telemarketing firms would be making 30 billion calls per year-approximately 0.8 calls per household per day. ${ }^{26}$ In fact, technological advances allow individual telemarketers to make many more sales calls per day. ${ }^{27}$ This phenomenon lends credibility to statements by consumer advocates and telemarketing experts suggesting that consumers receive an average of two or more calls per day. ${ }^{28}$

\section{B. Tragedy of the Commons}

The problem of externalized costs creates a second and related problem. The same legal regime that fails to address the industry's negative externalities also creates a tragedy of the commons. Like ranchers on a shared pasture or fishermen on an unregulated lake, telemarketers (and other direct marketers) over-consume a scarce resource: the time and attention of American consumers.

The problem of externalized costs alone is sufficient to justify our proposal to create a privacy market. But understanding the tragedy of the commons suggests that creating a privacy market may even be in the direct marketers' long-term interests. Telemarketers in the current regime not only ignore how their calling burdens callers, they also fail to consider how their individual calls burdens other telemarketers. The tragedy of the commons is thus another kind of externalized cost problem in which one telemarketer does not consider the costs that its marketing imposes on other telemarketers. These two dimensions of externalized costs perversely interact to unravel the market. As households increasingly drop out of the

25 Gene Haschak, Beware of Money Scams That Prey on Older Adults, CHI. DaILY HERALD, Mar. 16, 2001, at 2 (citing FBI statıstics). The telemarketıng industry has enjoyed enormous growth during the last decade. DiRECT MARKETING ASSOCIATION, 2000 ECONOMIC IMPACT: U.S. DIRECT MARKETING TODAY EXECUTIVE SUMMARY: KEY FINDINGS, available at http://www.the-dma.org/library/publications/libres-ecoimpact2.shtml.

26 This calculation is based upon approxımately 105 million U.S. households as measured by the 2000 Census. See U.S. Census Bureau, American Fact Finder, Households, at http://factfinder.census.gov/servlet/DTTable?_ts=31246255641 (last visited Feb. 8, 2002).

27 According to industry estimates, America's ten largest telemarketıng companies now have the capacity to call every U.S. phone number once a month. See Brian Brueggemann, Illinois State Representative Introduces Anti-Telemarketer Bill, BELLEVILLE NEWS-DEMOCRAT, Dec. 29, 2000 , at $1 \mathrm{~B}$.

28 Consumer advocacy websites report that the average American receives two to three calls per day from telemarketers. E.g., Antitelemarketer.com: Facts You Should Know About Telemarketing, at http://www.antitelemarketer.com/facts.htm (last visited Feb. 21, 2002); Did You Know...?, at http://www tommabe.com/facts.php (last visited Feb. 21, 2002); Telemarketing Statistics, at http://www.dianamey.com/Telemarketıngstats.html (last visited Feb. 21, 2002); Telemarketing Stats, at http://www.callmenot.com/about_stats.phtml (last visited Feb. 21, 2002). James R. Rosenfield, one of America's leading direct marketing experts, writes that on an average evening he receives five telemarketıng calls. See James R. Rosenfield, What Could Be More Successful Than Telemarketing?, 58 DiRECT MARKETING 14, 14 (1996). Thirty to forty telemarketing calls a week are simply too many. Id. at 15 . 


\section{Marketing Privacy}

are receptive to telemarketing calls. In light of these constraints, one option is to rely on anecdotal reports that response rates have decreased over time. ${ }^{33} \mathrm{~A}$ better approach, however, is to document the precipitous decline in response rates to public opinion polls conducted by phone. ${ }^{34}$ Unlike telemarketing firms, polling organizations occasionally share their response rates with researchers and journalists. ${ }^{35}$ In addition, there is less ambiguity about what constitutes a response to a survey. And quite apart from its value as a proxy, a decline in polling response rates will also be of interest because "a low response rate is one of the few outcomes or features that-taken by itself-is considered a major threat to the usefulness of a survey." 36

Polling response rates appear to have declined dramatically over the past few decades. ${ }^{37}$ One leading authority observes that in their heyday

33 See, e.g., Rosenfield, supra note 28 , at 14 (noting that telemarketing "closure rates" had decreased); Scott Hovanyetz, Newsday Set to Outsource Teleservices, DiRECT MARKETING NEwS, Apr. 26, 2001 (quoting a spokesperson for Newsday, a dally paper with a circulation approaching 600,000 , who observed, "We were finding [telemarketing] was becoming less and less successful.").

34 Consumers' frustration with the large and growing number of sales calls they receive is not necessarily the only factor behınd the drop in polling response rates. Charlotte $G$. Steeh, Trendis in Nonresponse Rates, 1952-1979, 45 PUB. OPINION Q. 40, 40, 44-48 (1981), observes that demographic changes - in particular, rising levels of urbanization-account for part of the change. Another factor may be the rising prevalence of "false surveys"-instances in which telemarketers ask consumers to participate in an alleged poll or survey but subsequently make a sales pitch. See Stephen Schleifer, Trends in Attitudes Toward and Participation in Survey Research, 50 PuB. OPINION Q. 17, 20, 22 (1986) (observing that the percentage of consumers subjected to a false survey in a given year rose from $13 \%$ in 1980 to $17 \%$ in 1984). In addition, consumers could be responding to growth in the volume of phone surveys instead of, or in addition to, growth in the number of sales calls. See Don Van Natta, Jr., Polling's 'Dirty Secret': No Response, N.Y. TimES, Nov. 21, 1999, § 4, at 1 ("Thanks to the ever-rising number of opinion polls and telemarketıng phone calls . . . more and more people simply refuse to be questioned."). Finally, fans of Arianna Huffington-and other persons upset by the extent of politucians' reliance on polls-may believe they are promotıng the public interest when they refuse to participate in surveys. See infra note 36 (discussing Huffington's crusade against polling). Nevertheless, the dramatic decrease in polling response rates is at least consistent with the tragedy of the commons hypothesis-the view that overconsumption of consumers' time and attention renders them more determuned to protect their solitude against unsolicited intrusions. See also Van Natta, supra, at 1 (quoting a pollster who attributes the growing number of refusals to the public's weariness with aggressive telemarketers).

35 Though more forthcomıng than telemarketers, pollıng organizations are also closemouthed about response rates. Van Natta, supra note 34, at 1, writes, "Far fewer people agree to participate in surveys than just 10 years ago, a fact that some critics call the industry's 'dirty little secret,' because most polling firms refuse to divulge therr surveys' refusal rates."

36 Richard Curtin et al., The Effects of Response Rate Changes on the Index of Consumer Sentiment, 64 PUB. OPINION Q. 413, 413 (2000). But note that at least a small number of commentators belıeve that declıning response rates to public opınion rolls are desirable-precisely because they undermine the polls' reliability. See Arıanna Huffington \& Harry Shearer, Arianna Online, Partnership for a Poll-Free America, at http://www.ariannaonline.com/crusades/ppfa.html (last visited Feb. 10, 2002) (arguing that public opinion polls have tumed our politıcal leaders into "spıneless followers" and urging visitors to submit a written pledge to refuse to answer pollsters' questions) [hereinafter Partnership for a Poll-Free America]

37 See generally Evans Witt, People Who Count: Polling in a New Century, PUB. PERSP., July-Aug. 2001, at 25-26 ("As pollsters, we worry about declınıng response rates and technological advances that make it harder and harder to get respondents on the telephone."). Response rates for surveys conducted by mail have also declined. See Richard J. Fox et al., Mail Survey Response Rate, 
phone surveys garnered response rates of $65 \%$ to $70 \%{ }^{38}$ Just ten years ago, response rates were typically at least $50 \% .^{39}$ Today, pollsters report response rates as low as $15 \%$ or $20 \%{ }^{40}$ One academic study shows that the percentage of respondents who refused to be interviewed increased sharply between 1952 and $1979 . .^{41}$ One indication that low response rates have become a serious problem for researchers is the fact that speakers at the polling industry's premier gathering, the annual meeting of the American Association for Public Opinion Research ("AAPOR"), have devoted enormous attention to the topic. The 1999 AAPOR, for example, featured 6 panels and at least 17 presentations on the subject. ${ }^{42}$

Response rates to direct mail and spam have also declined precipitously. Though statistics are not available for the entire direct mail industry, ${ }^{43}$ marketing firm BAIGlobal Inc. has been tracking response rates to credit card mailings since the mid-1980s. Response rates hit a new low during each of the past four years. In 2000, the most recent year for which statistics are available, credit card companies mailed out a record-high number of solicitations (3.54 billion solicitations, up from 2.87 billion in 1999) and their response rate declined from $1.0 \%$ in 1999 to just $0.6 \%{ }^{44}$ Gauging changes in email response rates-and ascertaining the causes of these changes - is difficult for three reasons. First, there are widely divergent views about what constitutes a "response." 45 Second, during the

52 PUB. OPINION Q. 467 (1988)

38 See Rebecca Buckman, Pollsters Increasingly Use the Net To Conduct Surveys; It May Be Easier, but Is It Science? WALL ST. J., Oct. 23, 2000, at R46 (reporting a statement by Gordon H. Black, chairman and CEO of polling firm Harris Interactıve Inc.).

39 See Van Natta, supra note 34, at 1.

40 See id.; Buckman, supra note 38 , at R43.

41 Steeh, supra note 34, at 40,44 (showing that refusal rates for the National Election Studies grew from $6 \%$ in 1952 to $23 \%$ in 1979 and refusal rates for the Surveys of Consumer Attitudes increased from approximately $5 \%$ in 1953 to $16 \%$ in 1976). A more recent paper reports that response rates declined only slightly between 1979 and 1996, but "the effort to obtain that result . . increased dramatically over tıme"; both the mean number of calls to complete an interview and the number of cases in which the poll-taker "converted" a respondent who initially refused to participate approximately doubled during the period of study. See Curtin et al., supra note 36, at 414.

42 See Michael W. Link \& Robert W. Oldenick, Call Screening: Is It Really a Problem for Survey Research?, 63 PUB. OPINION Q. 577, 577 \& n 1 (1999).

43. Pete Hisey, Keeping What's Yours on the 'Net, CREDIT CARD MGMT., June 1, 2000, available at $2000 \mathrm{WL} 10684253$, writes that response rates to direct mall pieces have hit all-time lows. His principal source, however, appears to be the same BAIGlobal studies discussed in the body of this Article, rather than additional, systematic research on the entire direct mail industry. See generally Petty, supra note 4, at 45 (citıng Susan Headden, The Junk Mail Deluge, U.S. NEWS \& WORLD REP., Dec. 8, 1997, at 42, 48, who states that half of all direct mall is disposed of without examination).

44 See Calmetta Coleman, Credit-Card Offers Get Record Low in Response Rate, WALL ST. J., Mar. 19, 2001, at Bl0 (citıng survey by BAIGlobal Inc.); Press Release, BAIGlobal Inc., Overall Credıt Card Response Rate at Record Low for 1997 (Mar. 1998), available at http://www.baiglobal.com/Archives/PR0398.htm. Coleman, supra, at B10, writes, "Andrew Davidson, president of the firm's competitive tracking services, sald consumers shrugged off so many offers last year [2000] largely because there were so many of them."

45 For an account of the different measures of consumer response, see Boldfish, Ways To Measure Email Campaign Response Rates, at http://www.boldfish.com/BF_emguide/Notes/ 
early years of Internet advertising, there were few if any entities using rigorous methodologies to document its development. Third, unlike other direct marketing mediums, the Internet has experienced rapid demographic changes over the past several years. These constraints aside, industry participants generally agree that spam response rates have declined to just a fraction of one percent-and that most of these responses are hate mail, notices of undelivered email, and messages requesting removal from the mailing list. ${ }^{46}$ A leading Internet research firm predicts that during the coming years as the volume of spam continues to rise, response rates will fall even further. ${ }^{47}$

The rising volume of unsolicited solicitations has also fueled the growing popularity of services that block direct marketing. Consumers' efforts to avoid telemarketers are especially well-documented. The states with "don't-call" lists in operation for more than a few years have recently experienced explosive growth. Florida, for example, became one of the first states to create a "don't-call" list back in 1990. The number of consumers registered with the Florida list has increased by more than $370 \%$ during the last 5 years. ${ }^{48}$ States that created lists during the past couple of years have also experienced enormous demand. Six months before the Tennessee don't-call list became operational, the director of the Tennessee Regulatory Authority's Consumer Division reported that his agency was already "swamped" with an "onslaught of calls" from persons anxious to register for the list. ${ }^{49}$ New York residents, meanwhile, registered well over one million phone numbers for the state's "don't-call" list during the six month interval before the list became operational. ${ }^{50}$

response.html (last visited Feb. 11, 2002), describıng the different standards for measuring consumer response to email advertisements. Possible measures include open (view) rate, click-through rate, conversion rate and acquisition rate. $I d$.

46 See, e.g., Un Raz, Permission Based Opt-In Email Marketing, at http://www.unitedmarketınggroup.com/target.html (last visıted July 14, 2001); WSP Advertısing Agency, Opt-In Email Marketing, at http://www.wspromotion.com/newsletter.html (last visited Feb. 11, 2002); see also Roberta Furger, Email's Second Shot, UPSIDETODAY, http://www.upside.com/texis/mvm/ story?d=38c93c990 (last visited Feb. 11,2002) (noting that a large-scale spammer's response rate had fallen by nearly $38 \%$ ). But see Furger, supra (reporting that spam response rates ranged from $2 \%$ to $10 \%)$.

47 See Keith Regan, Report: Email Marketing To Reach \$7.3B by 2005, E-COMMERCE TIMES (May 9, 2000), http://www.ecommercetimes.com/perl/story/3265.html (recounting predictions by Michele Slack, senıor analyst at Jupiter Communications, and summarızing a Jupiter research report unavalable to the public).

48 The number of people registered for the Florida don't-call list grew from 36,986 in 1996 to 136,913 in 2001 . The generally low number of registrants is likely attributable to the lack of consumer awareness, see infra text accompanyıng note 101, and the high cost of registration; Florida residents pay $\$ 10 /$ number for their first year on the list and $\$ 5 /$ number for each additional year. Interview with Beth Evans, Regulatory Consultant, Florida Department of Agriculture and Consumer Services (July 8,2001 ).

49 David Flessner, 'Don't Call' Pleas Grow in Tennessee, Times \& Free Press, Jan. 6, 2000, avalable at http://www.tımesfreepress.com/2000/JAN/06JAN00/NEWS3.html.

50 New York Governor George Pataki sıgned legislation creatıng the "Do Not Call" 
Connecticut just announced that during the first year in which its "don'tcall" list was operational more than 700,000 out of its 3.4 million residents opted out of the telemarketing pond. ${ }^{51}$ The number of consumers registered with the don't-call list that the Direct Marketing Association distributes to its members has also increased. ${ }^{52}$

At the same time, more Americans than ever before are paying for services that allow them to avoid phone solicitations. ${ }^{53}$ Between 1981 and 1996, the percentage of American consumers with unlisted phone numbers more than doubled-rising from $13.9 \%$ to $30 \% .{ }^{54}$ Caller ID was not available in all fifty states until $1996,{ }^{55}$ but already $39 \%$ of Americans subscribe to the service. ${ }^{56}$ BellSouth is one of three Baby Bells that recently introduced a proprietary service to block telemarketing calls; though the service, Privacy Director, costs $\$ 5.95$ per month plus a onetime fee of $\$ 19.95$ as well as long distance and operator charges for each call intercepted, BellSouth reports that 150,000 customers have already signed up in Atlanta and South Florida alone. ${ }^{57}$ The popularity of services

Registry in October 2000. The Registry became effective on April 1, 2001. See New York State Consumer Protection Board, New York State Consumer Guide to the "Do Not Call" Telemarketing Registry, at https://www.nynocall.com/gurde.html (last visited Feb. 11, 2002). Durmng this period, consumers registered 1,160,467 phone numbers. Emall from Bill Bennett, Vice Presıdent, New York Consumer Protection Board (June 30, 2001).

51 Press Release, Connecticut Department of Consumer Protection, Telemarketer Pays $\$ 25,000$ to Consumer Protection for Violatıng State's Do No [sic] Call List Law (Sept. 6, 2002), available at http://www.state.ct.us/dcp/Press\%20Releases/Homesecurity902.htm. The Connecticut population figure was taken from U.S. Census Bureau, DP-1. Profile of General Demographic Characteristics: 2000, Geographic Area: Connecticut, at http://factfinder.census.gov/servlet/ BasıcFactsTable?_lang=en\&_vt_name=DEC_2000_SF1_U_DP1\&_geo_id=04000US09 (last visited Feb. 14, 2002).

52 DiRECT MARKETING ASSOCIATION, ECONOMIC IMPACT: U.S. DIRECT \& INTERACTIVE MARKETING TODAY/2000 TELEPHONE MARKETING (2001).

53 Private Citizen Inc. provides another alternatıve for individuals determined to avoid direct marketing. The company reports that thousands of Americans have pald between $\$ 10$ and $\$ 20$ for services designed to reduce direct mail or phone solicitations. When consumers purchase Private Citizen's anti-telemarketıng service, the company adds their names to a "don't-call" list that it mails at intervals to 1,500 telemarketers. If a telemarketer to whom this list has been malled nevertheless calls a Private Citizen customer, that customer can sue the telemarketer for $\$ 500$ per call. For more information about Private Citızen Inc., see Private Citizen, at www.privatecitizen.com (last visited Feb. 11, 2002).

54 Compare Frank NewPORT ET AL., Where AMERICA STANDS xiv (1997), with Roman, Telephone: The Growing Medium, in FACT BOOK ON DIRECT MARKETING 133 (1985 ed.), cited in Nadel, supra note 15 , at $100 \&$ n.13.

55 Calıformia was the last state to implement Caller ID. It activated the service on June 1 , 1996. See Utılity Consumers' Actıon Network/Prıvacy Rights Clearınghouse, Fact Sheet 19: Caller ID and My Privacy, at http://www, privacyrights.org/fs/fs 19-cıd.htm (last modified Aug. 2000).

56 See American Teleservices Survey, ATA Consumer Research, Feb./Mar. 2001, at http://www.ataconnect.org/htdocs/consinfo/consumer_study_march-feb0l.htm (last visited Feb. 11, 2002). The American Teleservices Association sponsored two telephone surveys on February 16 through 18 and March 2 through 4, 2001 of 1,000 consumers about their use of telephones, the Internet, and related services. The research was conducted by Market Facts, Inc.

57 See Karın Schıll Rives, BellSouth Telemarketing Call-Block Service Rejected in North Carolina, NEWS \& OBSERVER, Aug. 4, 2000, available at 2000 WL 24910815. 
such as Privacy Director and Caller $\mathrm{D}$, meanwhile, seems slight when juxtaposed against the ubiquity of anti-spam software. Every major email provider incorporates spam-blocking measures into its standard package. Indeed, companies such as Earthlink, America Online and Hotmail now seek to differentiate their services by advertising the particular technologies they have developed to fight spam. And this past winter, the "telezapper"- a device that emits a sound to induce autodialers to disconnect-was aggressively marketed as the perfect Christmas gift. ${ }^{58}$

These self-protective measures are all evidence of the massive problem of overfishing. Current law makes household privacy a "commons" where marketers are tragically allowed to graze without restraints. And as happens in other "tragedy-of-the-commons" contexts, when the target population dwindles, the problem (of overfishing or overgrazing) accelerates as competitors rush after the shrinking pool to get their share.

\section{Current Legislative Reponses}

The primary legislative response has merely been to facilitate household interdiction-in essence to help households achieve through law what they have been trying to achieve through technology (the telezapper and caller ID) and behavior (the venerable hang-up). The first step in facilitating household interdiction of nuisance telemarketing calls came in 1991. The TCPA, the first and still the most important federal legislation regulating telemarketing, found that "[m]any customers are outraged over the proliferation of intrusive, nuisance calls to their homes from telemarketers." ${ }^{59}$ The TCPA authorized the FCC to bar telemarketers from calling consumers who registered their phone numbers with a nationwide "don't-call list" - and prohibited telemarketers from soliciting any consumers during the night or early morning. An intense lobbying campaign by the direct marketing industry convinced the FCC to adopt a similar but less consumer-friendly version of the "don't-call" approach. In place of a national "don't-call" list, the FCC issued regulations providing that when a consumer asks a specific telemarketer to stop calling, the telemarketer is legally required to comply with the request.

58 At the time that this Artıcle was being written, Telezapper was available at Amazon.com, at http://www.amazon.com; MSN eShop, at http://eshop.msn.com/; and Yahoo Shopping, at http://shop.store.yahoo.com/phonesphonesphones/telteldet.html. Telezapper's homepage can be found at http://www.telezapper.com/default.asp.

59 See Congressional Statement of Findings, Pub. L. No. 102-243, § 2; 47 U.S.C. $\$ 227$ (2001). United States Senator Eamest "Fritz" Hollings stated the point more poetically durıng his introduction of the Automated Telephone Consumer Protection Act; he observed, "They wake us up in the moming; they interrupt our dinner at night; they force the sick and elderly out of bed; they hound us unt1l we want to rip the telephone right out of the wall." 137 CONG. REC. 30821 (1991). 
Meanwhile, states have been rushing to create "don't-call" lists that prohibit telemarketers from calling any household number that is listed. In 1994, six states had passed these "don't-call" statutes. ${ }^{60}$ But now there are more than twenty states that have or are about to have "don't-call" legislation in effect. ${ }^{61}$ These state laws mirror Congress' assessment of the problem as well as its problem-solving approach of facilitating household interdiction of telemarketing calls. ${ }^{62}$ Most recently the FTC has proposed a nationwide "do-not-call" registry that is based on the state models. ${ }^{63}$

Academics to date have also focused on blocking phone solicitations-sometimes recommending that the "don't-call" approach be amplified by requiring consumers to affirmatively opt-in (by registering on a "please-call" list if they want to grant telemarketers permission to call) or creating a nationwide list. ${ }^{64}$ In each case, long anecdotes depicting telemarketing calls as a nuisance precede the authors' recommendations that government should do more to suppress it. ${ }^{65}$

State legislatures have also become more active participants in the struggle to curb spam and phone solicitations. In July 1997, Nevada became the first state to enact anti-spam legislation. ${ }^{66}$ By November 1999 , four states had passed statutes regulating the transmission of unsolicited

60 Rita Mane Cain, Call Up Someone and Just Say 'Buy'-Telemarketing and the Regulatory Environment, 31 AM. Bus. L.J. 641, 666-98 (1994). The six states that had created "don'tcall" Iısts were Arizona, Flonda, Lousiana, New Jersey, Oregon, and Utah. Id.

61 See supra note 5.

62 See, e.g., CONN. GEN. STAT. ANN. § 42-288a (West Supp. 2002) (creating a don't-call list and restrictıng the hours that a telemarketer may call).

63 See, e.g., Proposed National "DO NOT CALL" Registry, available at http:/www.ftc.gov/bcp/conline/edcams/donotcall/ndex.html (last visited Nov. 9, 2002). As this Artıcle was in final production, the FTC amended its telemarketing sales rule, creatıng a do-not-call registry. See federal TRAde COMMISSION, Final AMENDED Rule and ACCOMPanying STATEMENT OF BASIS AND PURPOSE, available at http://www.ftc.gov/os/2002/12/tsrfrn.pdf.

64 See, e.g., Joseph R. Cox, Telemarketing, the First Amendment, and Privacy: Expanding Telemarketing Regulations Without Violating the Constitution, 17 HAMLINE J. PUB. L. \& POL'Y 403, 421-22 (1996); Nadel, supra note 15, at 101, 121-27; Sovern, supra note 15, at 1101-18.

65 The opening paragraph of Cox, supra note 64 , at 403, is typical:

How often does it happen to you? You sit down to have dinner in the early evening, probably enjoyıng pleasant conversation with your famıly, when the phone rings. The caller asks for you or your spouse by first name. But you know it is not a friend; you have been through this routıne too many tımes. "What are you sellıng?" you ask. The caller laughs gently and suggests that nothing is for sale, this is merely a "courtesy call." The caller asks if you have ever thought about aluminum siding for your house. Yes, you reply, you thought about it fifteen years ago when you had it installed. If it is not aluminum siding being peddled, it is credit cards, newspaper subscriptions, long distance service or any number of products or services you either already have or are not interested in obtaning. And perhaps like many people, even if you happened to be interested in the product or service, you would not purchase it over the phone during dinner.

For other examples, see Nadel, supra note 15, at 99 (discussıng compulsion one feels to answer one's phone) and Sovern, supra note 15, at 1069-70 (describing problems with mailed solicitations).

66 See NEV. REV. STAT. $\S \S 41705-.735$ (2002). 


\section{Marketing Privacy}

commercial emails. ${ }^{67}$ Today, at least eighteen states have enacted antispam laws. ${ }^{68}$ These laws range from provisions banning deceitful practices such as "spoofing" or requiring mandatory labeling to laws banning spam outright. ${ }^{69}$ The U.S. Congress is also considering a variety of anti-spam measures. $^{70}$

The recent behavior of legislators (like the self-protective strategies of consumers themselves) corroborates the tragedy of the commons hypothesis. Each kind of solicitation disturbs a consumer's solitude to some degree. $^{71}$ The frequency with which direct marketers invade consumers' physical privacy has left consumers weary of solicitations and resentful of the direct marketing industry. ${ }^{72}$ In the none-too-distant future,

67 See Matthew S. Brown et al., Spam Doesn't Come Only in Cans: A Summary of the Current Law Regarding Unsolicited Commercial Email, 4 CYBER L. 19, 21 (1999). Those four states are Californıa, Nevada, Vırginia, and Washıngton. Id.

68 David E. Sorkın, Spam Laws: United States: State Laws: Summary, at http://www.spamlaws.com/state/summary.html (last visited Feb. 11, 2002) summarızes state ant1-spam laws. But the summary is incomplete. For example, Professor Sorkın discusses Virgınıa legislation prohibiting "spoofing," but omits mention of other Virgınıa legislation that bans spam outright and imposes crimınal as well as civil penalties on spammers. (Spoofing means falsıfyıng the origin or delivery route of an email.) For a description of the more stringent components of Virginıa ant 1 -spam law, see Maria Semınerio, Spam Outlawed by Second State, ZDNET NEWS, Feb. 23, 1999, at http://www.zdnet.com/zdnn/stories/news/0,4586,2215334,00 html.

69 There are five basic kinds of anti-spam provisions. Most states that have adopted antispam legislation have adopted more than one type of provision. First, at least eight states (Cahfornia, Colorado, Idaho, Iowa, Missourı, Nevada, Rhode Island and Tennessee) require spammers to include in unsolicited commercial emails instructions about how to opt-out of future emails and at least seven states (all of the aforementioned states except Missouri) require individual spammers to honor opt-out requests. Second, at least five states require spammers to place a label (such as "ADV:") in the subject heading of all or some types of unsolıcited commercial emals. These states are Californa, Colorado, Nevada, Pennsylvania and Tennessee. Third, at least thirteen states prohibit spoofing-falsıfyıng the ongin or delivery route of an emall. These states are Calıfornı, Connectıcut, Delaware, Idaho, Illınoıs, lowa, Louısıana, North Carolına, Oklahoma, Rhode Island, Virgınıa, Washıngton and West Virginia. Fourth, at least three states (Calıfornia, Loussiana and Tennessee) require that spammers comply with an Intermet service provider's (ISP) spam policy. Fifth, at least two states (Delaware and Virginıa) prohibut spam outright. This survey of state anti-spam legislation was compiled principally from the resources available at http://www.spamlaws.com.

70 Coalition Against Unsolicited Commercıal Email, Pending Legislation, at http://www.cauce.org/legıslation/ındex.shtml (last modified Apr. 26, 2001) (summarizing anti-spam legislation introduced during past and current sessions of Congress). The House of Representatives passed an earlier version (H.R. 3113) of one pending bill (H.R. 95) during the 106th Congress (1999); H.R. 3113 and H.R. 95 would require senders of unsolicited commercial email to comply with an ISP's spam policy. Id.

71 In a 1995 survey, for example, $56 \%$ of consumers reported that unsolicited sales calls were a serious violation of privacy. Telemarketıng was more widely regarded as a serious violation of privacy than the imposition of polygraph, AIDS or drug tests by employers. See And Don't Call Back, ADWEEK - W. EDITION, Nov. 13, 1995, at 22 (presentung results of a Yankelovich Montor poll).

72 Some consumers-and public officials-are more resentful than others. During a heated debate in the Texas State Legislature about a proposed don't-call list, Representative Burt Solomons exclaimed, "If it were up to me, we would shoot telemarketers." State Legislator: Shoot the Telemarketers, DM NEwS, Apr. 18, 2001, quoted in Califormans Against Telephone Solicitation, Quotes from 2001, at http://www.stopjunkcalls.com/quote01 htm (last visited Feb. 12, 2002). The trial judge in State v. Wagner, 608 N.E.2d 852 (Oho Ct. App. 1992), expressed similar sentıments, remarking, "There are times when I just want to take a shotgun and, if I could shoot them through the phone, I'd do it." Id. at 856. 
spammers, telemarketers, direct mail specialists and door-to-door salesmen may all find themselves fishing the same empty lake.

\section{The Market Solution}

The government can solve the tragedy of the commons and negative externalities problems by empowering consumers to set prices at which they are willing to receive different kinds of unsolicited solicitations. In essence, this approach creates a market for physical privacy. ${ }^{73}$ Currently, telemarketers start out with the entitlement to call residents. Residents can often take action to take back this entitlement (by paying for an unlisted number or in some jurisdictions by adding their names to a "don't-call" list). But residents do not have an effective means of selling their physical privacy to telemarketing firms. A resident's right to avoid unsolicited solicitations is thus effectively what Susan Rose-Ackerman termed "market inalienable."74 Residents can give away their privacy right (by failing to block such calls) or they can take steps to perfect their privacy rights, but they cannot sell their privacy right for money. The market inalienability of the consumer's privacy right vis a vis business stands in great contrast to businesses' privacy rights vis a vis consumers. For decades, businesses have used 1-900 numbers to force consumers to compensate the business for its time. Simply calling a 1-900 number triggers a per-minute payment from the consumer (easily collected through the consumer's telephone bill) to the business. The simple proposal of this Article is to eliminate this asymmetry by allowing residents to freely alienate their right to market privacy-that is, their right to be left unsolicited. ${ }^{75}$

explains

By referring to "physical privacy," we adopt the termınology of Anita L. Allen. She

The liberal conception of privacy is the idea that government ought to respect and protect interests in physical, informational, and proprietary privacy. By physical privacy, I mean spatial seclusion and solitude. By informational privacy, I mean confidentiality, secrecy, data protection, and control over personal information. By proprietary privacy, I mean control over names, likenesses, and repositories of personal identity.

Anita L. Allen, Coercing Privacy, 40 WM. \& MARY L. REV. 723, 723-24 (1999).

74 See Susan Rose-Ackerman, Inalienability and the Theory of Property Rights, 85 CoLum. L. REV. 931 (1985).

75 At first glance, it might seem that we are advocatıng what Gurdo Calabresi and Doug Melamed referred to as a "liability rule." See Guido Calabresi \& Douglas Melamed, Property Rules, Liability Rules, and Inalienability: One View of the Cathedral, 85 HARV. L. REV. 1089 (1972). But this is not so. With a liability rule regime, a lawmaker would set the price for a non-consensual taking by the telemarketer. Ian Ayres \& Paul Goldbart, Optimal Delegation and Decoupling in the Design of Liability Rules, $100 \mathrm{MICH}$. L. REV. 1 (2001). But in our regime, the household sets the price at which it wants to offer its telemarketıng tıme and the telemarketer can accept what then becomes a bilaterally consensual transaction. 
Part III will discuss the details of our proposals and a variety of regulatory choices that government needs to confront to implement a market system-including difficult questions concerning the boundaries of participation and the degree to which consumers can refine their pricing choices. But for now we discuss the relative merits and failings of a market approach at a more theoretical level.

A market approach would force direct marketers to internalize the costs they impose on consumers. ${ }^{76}$ As a result, a consumer would only receive a solicitation when the expected benefit to herself and the direct marketer exceeded the expected cost. ${ }^{77}$ While telemarketing would still be unsolicited in the micro sense, consumers would in a macro sense solicit calls by posting a price at which they would be happy to listen. We should emphasize that household members would not have a duty to listen to telemarketing calls - they could still hang up as soon as they saw fit. But our "name your own price" mechanism means that-in contrast to the current system-consumers would effectively consent to receive the call and hence express a willingness to listen to the beginning of the pitch. ${ }^{78}$ Accordingly, under our system both the speaker and the listener reveal their preferences to initiate the conversation-thus suggesting expected gains of trade.

Residents will benefit in three concrete ways. First, they will receive fewer telemarketing calls. Second, the calls they do receive are likely to be more interesting-because telemarketers facing additional costs of communication are likely to undertake additional efforts to restrict their sales efforts to the subset of consumers that are especially likely to be interested in purchasing that vendor's products. Consumers would have a simple means to adjust not only the volume of solicitations they received but also the frequency with which solicitations addressed their particular

76 See Petty, supra note 4 (discussing possibılity for using price mechanısms to internalize externalızed costs of various types of direct marketıng).

77 Our system would of course tolerate some inefficiencies. Viewed ex-post, the costs of some solicitations would exceed the benefits. The frequency with which particular solicitations would be ex-post efficient would depend on the level of nuance associated with consumers' price-setting behavior - in other words, whether consumers set a single price for all sales calls or designated different prices depending on factors such as the identity of the caller, the type of product being sold and the time of the call. Ex-ante inefficiencies, meanwhile, would result from any of the following factors: (1) taxation of the payments consumers received from direct marketers; (2) strategic pricing; or (3) the fact that the particular market-based approach detalled in this Article does not empower ISPs to charge spammers for the costs of transmitting unsolicited email advertisements-though ISPs could contınue to pass these costs along to consumers, who might in turn pass them along to spammers.

78 There is a sense in which residents in states with "don't-call" statutes who decline to optout can also be said to consent to receive telemarketıng calls. But, as argued below, the majority of citizens in these states do not know that they have this option. And the quality of consent when residents are given an all-or-nothing choice is not as high as when residents are given a range of choices. Some of the residents who fall to opt-out would prefer not to consent to some of the low-value calls, and some of the residents who do opt-out would be willing to consent to compensated telemarketıng. 
needs and interests. The more a consumer charges to listen to a phone solicitation, the more confident a prospective caller must be that the consumer will be receptive to his sales pitch. Finally, residents will receive a price that they individually deem to be adequate for the calls that they do receive.

In sum, our "name your own price" mechanism is likely to promote both social and consumer welfare. By revealing the preference of speaker and listener, our mechanism tends to filter out communications where the social cost is greater than the social benefit-promoting social welfare. By giving consumers more choices than all-or-nothing alternatives, our mechanism presumptively increases their welfare. ${ }^{79}$

Given that telemarketing is widely regarded as a pariah industry that exists in large part because of these uncompensated, externalized costs imposed on households, it is particularly unnecessary for either equitable or efficiency reasons to show that a move to our mechanism also benefits telemarketers. Indeed, our mechanism will not benefit many telemarketers who for the first time would be forced to compensate listeners for their time. Surprisingly, however, requiring telemarketers to compensate households can produce two different types of benefits for telemarketers themselves that mitigate the burden of compensation. And the telemarketers that make the most socially beneficial solicitations are likely to be the least harmed by the compensation requirement.

First, in at least one dimension, the "name your own price" mechanism increases the freedom of telemarketers by giving them the ability to compensate residents. As discussed above, ${ }^{80}$ consumers are displaying increased resistance to telemarketing calls. The response rates to telephone surveys are in steep decline and consumers are much less likely to listen to, much less respond to telemarketing pitches. Our mechanism enhances telemarketers' ability to generate willing listeners. Our system allows telemarketers at the beginning of the call to present a credible signal that the resident will be compensated for listening to the pitch. Household members hearing this signal may be much more willing to participate in the call.

The Gallup Organization and other polling firms might be willing to voluntarily offer compensation to residents (even if it were not required) in order to increase their response rates. ${ }^{81}$ We might initially worry that the

79 This context has none of the rare attributes that might cause choice to be disabling. See, e.g., Jennifer Gerarda Brown, The "Sophie's Choice" Paradox and the Discontinuous Self: Two Comments on Wertheimer, 74 DENV. U. L. REV. 1255 (1997).

80 See supra notes 33-35, and accompanying text.

81 Companies pay approximately two dollars for every minute that a randomly selected American spends answering a survey question. The company's per-minute payment to an average survey respondent would likely be a small fraction of this current cost. By increasing response rates, our approach would decrease the number of man-hours necessary to complete a survey. So our 
prospect of compensation would somehow bias the polling results. But these concerns would be misplaced. There is no reason to think that the answers of those who participated would be biased from what they would have been if they had not been compensated. The real concern is whether the polling organizations will ask a systematically non-random sampleavoiding the households that have named the highest prices. But this potential bias can be measured by comparing the average compensation paid in the survey to the average posted price in the population generally. Moreover, the bias under the current uncompensated system of having a ten to fifteen percent response rate is likely to be radically higher than the bias of having a compensated seventy percent response rate. The wild gyrations in the polls during the latest presidential election are largely attributable to the nose-dive in response rates. People are so intent on getting off the phone as soon as they sense that the call is unsolicited that they often don't try to distinguish a carpet cleaning pitch from political polling. Compensated marketing is likely to help telemarketers to mitigate this resistance. ${ }^{82}$

Second, telemarketers are benefited by the deregulation of the industry that naturally attends the movement toward compensation. Once a pricing mechanism empowers consumers to signal a willingness to receive telemarketing calls, it becomes unnecessary to impose stiff time and manner restrictions. Federal Communications Commission regulations authorized by the TCPA prohibit sales calls after 9 p.m. and before 8 a.m. ${ }^{83}$ and outlaw the use of recorded telephone solicitations not preceded

approach would reduce labor costs and long-distance charges. Our approach might actually allow polling organizations to save money. And as we argue, infra, text accompanying note 83 , it would improve polling accuracy.

82 There is a substantial hterature explonng how incentives improve response rates. This literature indicates that monetary incentives, especially prepaid or other certain rewards that are enclosed in the survey itself, significantly improve response rates. See, e.g., Raymond Hubbard \& Eldon Little, Cash Prizes and Mail Survey Response Rates, 16 J. ACAD. MARKETING SCI. 42 (1988); J. Scott Mizes et al., Incentives for Increasing Return Rates, 48 PUB. OPINION Q. 794, 800 (1984); Ruta J. Wilk, Research Note, The Use of Monetary Incentives To Increase Survey Response Rates, 29 SOC. WORK RES. \& ABSTRACTS 33, 33-34 (1993).

Researchers theorize that pre-payments improve response rates because fallure to complete the survey would produce cognitive dissonance in the respondents-they would feel cheap about keeping the dollar without completıng the task. If this theory is correct, then consumers are uncomfortable about receiving the money without performing the associated task. See, e.g., S. Oshikawa, Consumer Pre-Decision Conflict and Post-Decision Dissonance, 15 BEHAV. SCI. 132, 132-140 (1970); Wilk, supra, at 33-34. This reasoning suggests that consumers who recelved payments in return for accepting telemarketıng calls, spam or direct mail would actually give the unsolicited solicitations a good-faith read or listen.

For an example of how pollsters are using incentives and technology to compensate for declıning response rates, see Michael Lewis, The Two-Bucks-a-Minute Democracy, N.Y. TIMES MAG., Nov. 5, 2000, $\S 6$, at 65 . Lewis writes about Knowledge Networks, a start-up founded by two Stanford political scientists, that provides consumers willing to spend ten minutes per week answerıng surveys with a free Web TV, free Internet access and numerous prizes.

83 See FTC Restriction on Telephone Solicitations, 47 C.F.R. $\$ 64.1200(e)(1)(2002)$. 
by a live communication. ${ }^{84}$ Many states amplify these time and manner restrictions by requiring telemarketers to share key information — such as the nature of the call, the products being sold, and these items' prices-at the outset of the call ${ }^{85}$ prohibiting autodialers and pre-recorded messages (altogether) ${ }^{86}$ and/or further limiting the times of day when telemarketers can call. ${ }^{87}$ Telemarketing by fax and telemarketing to cell phones is also prohibited. ${ }^{88}$ These restrictions make great sense under the current marketinalienable regime, in which consumers cannot effectively sell their right to be left alone. But time and manner restrictions are prima facie inefficient in a system in which consumers are given the option of separately pricing alternative times and manners. There is no reason to have a blanket prohibition against 2 a.m. telemarketing calls if consumers have the option of naming a price at which they would welcome these calls.

While we do not predict that many consumers would opt to receive late night calls, ${ }^{89}$ we do imagine a more vibrant market in pre-recorded calls. The current prohibitions against pre-recording all grow out of the concern with externalized costs. If the telemarketers are going to impose individualized costs on listeners, we want them to have to pay speakers by the hour. But this concern evaporates once the consumer is paid what she deems to be adequate compensation.

Notice there is no movement afoot to prohibit pre-recorded commercials on television or radio. The programming that surrounds the commercial is the compensation for listening to the pitch. Indeed, imagine how much worse commercials would be if pre-recording were prohibited. Madison Avenue has discovered economies of scale-in the form of taped commercials. Repeatedly reproducing a live commercial would be unnecessarily expensive. If telemarketers were able to similarly concentrate their efforts into pre-recorded messages with high production

84 Id.

85 See, e.g., ALA. CODE $\$ 8$-19A-12 (West Supp. 2001) (requiring telephone solicitors to identify themselves by name, the name of the company on whose behalf they are calling, and the nature of the good or service being offered within the first thirty seconds of the phone call).

86 See, e.g., UTAH CODE ANN. § 13-25a-103 (Supp. 2001) (prohibiting all use of automatic dialers except to dial numbers at which the recipient has consented to receive calls from autodialers or with whom the caller has a prior business relationship).

87 See, e.g., CONN. GEN. STAT. § 42-288a(c)(2) (2002) (prohibiting unsolicited sales calls between the hours of 9 p.m. and 9 a.m.).

88 See 47 U.S.C. $\$ 227(b)(1)(C)(2001)$ ("It shall be unlawful for any person in the Unıted States ... to use any telephone facsimile machıne, computer, or other device to send an unsolicited advertısement to a telephone facsimile machıne"); 47 C.F.R. $\S 64.1200$ (a)(3) (2002) ("No person may - [u]se a telephone facsimile machine, computer, or other device to send an unsolicited advertısement to a telephone facsimile machine.").

89 Some noctumally-minded graduate students will probably find the federal regulation requirıng telemarketers to call between $8 \mathrm{a} . \mathrm{m}$. and $9 \mathrm{p} . \mathrm{m}$. to be suboptimal. Instead, they will prefer to set a low price for calls between $11 \mathrm{a} . \mathrm{m}$. and $2 \mathrm{a} . \mathrm{m}$. and a much higher price for calls at other times. 
values, we could expect a better product than we often hear in the monotone renderings of minimum-wage script readers. The pre-recorded seatbelt warning by celebrities in New York City taxis are likely to be more entertaining than wamings by the cabbies themselves.

If telemarketers were given the freedom to use pre-recorded messages delivered through autodialers, ${ }^{90}$ we imagine that the telephone might become a competitive outlet for polished advertisements (at least rivaling the radio). By targeting consumers with special interests, local grocery stores, movie theaters, bookstores or music clubs could provide valuable information about sales or special offers. Indeed, the same spots that are produced for radio might be transmitted over the telephone at relatively low marginal cost.

With compensated calling, some consumers may be tempted to prolong calls or to simply put the phone down just to increase the compensation. But keeping the consumers' attention is also a problem with television and radio advertisement-after listening to the entertainment programming which the advertiser paid for, the consumer may go to the bathroom during the commercial. As in these other media, the marketer can increase the attention given by making the pitch more interesting. And we might imagine telemarketers asking the compensated listener to periodically press a button (e.g., answer a trivial question) in order assure that someone was really listening.

More generally, compensated calling creates problems of adverse selection. Households that are not really interested in hearing the advertisement might just sign up for the compensated calling to make money. Some marketers currently try to control for this by offering compensation in kind; time-share properties might offer a free weekend stay in return for customers' listening to a sales pitch to buy a similar unit. Adverse selection problems might stop some telemarketers from offering compensation. It should be noted, however, that adverse selection does not stop marketers from advertising on television, where the type of compensation (sitcoms, news reports) is often orthogonal to the products being pitched. And telemarketers can mitigate adverse selection in our system by simply refusing to call anyone who has set a rate that seems to be supra-compensatory.

At the end of the day, some telemarketers might opt for compensation-especially if it were bundled with deregulation. Thus, while the "name your own price" regime does not constitute a strict Pareto improvement for the entire telemarketing industry or even the subset of telemarketers with socially beneficial products, our mechanism represents

90 Note that a market regime could allow consumers to set different prices for live and recorded pitches. 
a strong Kaldor-Hicks social improvement-one which benefits all consumers, benefits some telemarketers and falls short for other telemarketers in proportion to the social inefficiency of their activity. To our minds, this makes out a strong argument in both equity and efficiency for thinking that the proposal is superior to the status quo.

\section{A. Comparison with Improved Initial Disclosure}

While we strongly prefer the market-based approach, mandating improved disclosure by direct marketers is likely to mitigate the worst costs of the current system-without introducing telemarketer payments. While both state and federal law require certain kinds of disclosure, the current rules are ineffective either because the disclosure format is nonuniform or because the duty to disclose is only triggered by a specific request for information from the resident. For example, the TCPA requires the telemarketer to give a whole host of information to householdsincluding mailing the telemarketer's procedures for complying with a "no more calls" request ${ }^{91}$-but the duty to disclose this information is contingent on a specific request. Woefully few individuals know they have these rights, and much of the information is of little use. Some states have usefully amplified the disclosure obligations by requiring telemarketers at the outset of the call to share key information-such as the nature of the call, the products being sold, and these items' prices. ${ }^{92}$ But the format of this disclosure is not standard and again few consumers are aware of their state-law rights to information-so that enforcement and compliance are sorely lacking.

Instead, what is needed is quite simple. Statutes should require that telemarketing calls begin with a simple sentence: "This is an unsolicited telemarketing call." Requiring a uniform disclosure at the beginning of the call would give consumers a much more efficient means of screening unwanted calls than exists today. The uniformity of the disclosure-like the uniformity of the Miranda warning-would quickly make consumers aware of the disclosure duty and put them on notice when a telemarketer was in non-compliance. If consumers are given a bounty for reporting violations, non-compliance should become relatively rare. ${ }^{93}$

Currently, direct marketers and their victims engage in an endless catand-mouse game in which marketers try to initially disguise with a variety

91 See 47 C.F.R. $\$ 64.1200(\mathrm{e})(2)(1)(2002)$.

92 See supra note 85.

93 This is especially true in states that allow unannounced recording of telephone conversations. Residents who have the potential of receiving, say, $\$ 200$ for reporting a non-complying call might have sufficient incentive to automatıcally tape record all their calls-à la Nixon-and thus would have fairly conclusive evidence of non-compliance. 
of ruses the true nature of the call until they have the listeners psychologically committed to listening. For example, who hasn't heard a call begin with feigned familiarity- "May I please speak with Joe ...?"

The idea of requiring standardized disclosure at the beginning of a telemarketing call resonates deeply with long-standing practice concerning collect calls. Instead of hearing "Collect call from Jane Doe, do you want to accept the charges?" households in effect would be hearing "Telemarketing call from X, do you want to accept the inconvenience?"

Indeed, far from prohibiting pre-recorded telemarketing calls, the law should require that the disclosure be pre-recorded. Requiring a prerecorded initial announcement would give the recipient information and the psychological freedom to disconnect before the substantive pitch begins. It is much easier to hang-up on a recording than a live human on the other end. The telemarketers ruthlessly exploit this deeply ingrained norm of reciprocity to make listeners feel like schlemiels if they heartlessly cut-off a real person who is just trying to do her job. The federal law gets it just backward: it insists that pre-recorded messages be preceded by a live message, when we should instead require that any live message be preceded by a pre-recorded disclosure.

It would even be possible to frame the disclosure so as to allow even more passive types of consumer filtering. Requiring the message to include a uniform set of tones would allow consumers to install a device that would automatically disconnect telemarketing calls. Or telemarketers could be required to call from pre-designated telephone numbers that would allow Caller $\mathrm{D}$ devices to automatically block the call before it caused the resident's phone to ring. ${ }^{94}$ Facilitating passive filtering is important, because even standardized initial disclosures that are verbal will not eliminate the burden of having to pick up an unwanted call.

Mandatory disclosure might also be a crucial complement to a voluntary market in telemarketing compensation. Imagine what might ensue if the mandatory disclosure added the second clause "and the telemarketer will credit your phone bill for $\mathrm{xx}$ cents for each minute you participate in this call." Under this voluntary system, the telemarketer would not be required to compensate the listener, but would need to disclose that no compensation was being offered ("zero cents"). We predict that this factual disclosure as to the purpose of the call and the offered compensation would cause some telemarketers to volunteer compensation-a possibility that we will return to below in Part III.B.

A requirement of straightforward, standardized, initial disclosure would also eliminate much of the current abuse of junk mail and spam.

94 Instead of blocking telemarketing calls, a new-fangled caller ID device might emit a distinctive ring warning the household of an unsolicited solicitation. 
Imagine how much simpler it would be to sort your mail if unsolicited mass mailings had to include an encircled " $J$ " in the lower-left hand corner (below the recipient's address). Instead of the current cat-and-mouse game, where junk mailers try to make their solicitations look like checks, tax documents or registered letters and recipients waste time trying to decode the true intent of the sender, the circled "J" requirement would allow any recipient to simply throw away the unwanted mail. Or think how devastatingly simple it would be to filter out spam if all such email had to include a uniform stream of characters-say "Unsolicited Commercial Email" or "UCE" - in the subject line.

Standardized, initial disclosure is superior to state and national "don't -call" lists and technological filters (such as Caller ID). ${ }^{95}$ But disclosure shares with these other measures the basic impulse to interdict (or to allow consumers to interdict) unwanted telemarketing calls. The next Section probes whether our market-based approach dominates the variety of efforts at interdiction.

\section{B. Comparison with Private and Public Interdiction}

To persuade the reader that our system of alienable market privacy is worthwhile, it is useful to compare our proposal not just to the status quo but also to alternative reform proposals. Fortunately for this analysis, all of the existing and proposed regulatory efforts to curb telemarketing abuse share a common goal of interdiction. These alternatives either would (i) flatly prohibit entire classes of telemarketing (on the theory that no reasonable consumer would want to listen to them) or (ii) empower the consumer to prohibit certain classes of telemarketing calls.

The first type of regulation includes the aforementioned outlawing of nighttime calls, of pre-recorded calls and of the use of autodialers. ${ }^{96}$ The second kind of regulation includes our own (standardized, initial) disclosure proposal as well as the more traditional filtering options of allowing unlisted numbers, Caller $\mathrm{ID}^{97}$ and private opt-out services (such as Privacy Director) that make consumers less accessible to

95 While the state-enforced "don't-call" lists arguably provide a simpler, one-tıme mechanism for vetoing all telemarketing calls, the lists, which have been around in some states for up to 12 years, have had very low visibility. And the more cumbersome self-filtering facilitated by disclosure would quickly become known by all consumers (and like Miranda would likely become part of popular culture with references in movies and television).

96 See Rosenfield, suprn note 28.

97 Caller ID 1s, at present, a farrly ineffective mechanism for screening out phone solicitations, because the devices are frequently unable to identify telemarketing calls as such. Autodialers use a special kind of phone line (an ISDN line) that allows telemarketers to control what your Caller ID box says. Unsurprisingly, they generally choose not to identify themselves in the Caller ID box as telemarketers. See DENNIS HAWKINS, supra note 21, at 2. 
telemarketers. $^{98}$ The nation's largest direct marketing trade association (the Direct Mail Association) itself has attempted to forestall federal regulation by requiring its members to at least notionally refrain from calling persons on its national opt-out list, the Telephone Preference Service ("TPS"). ${ }^{99}$ The federal TCPA requires telemarketers to honor consumers' requests not to receive additional sales calls from a particular company. And twenty states have gone further in facilitating consumer interdiction by passing "don't-call" statutes that allow consumers to opt-out of all unsolicited commercial telemarketing calls in advance. These "don't-call" statutes combine the advantages of the TPS and the TCPA in that they have the force of law and they are truly unified ex-ante, opt-out systems.

Professor Jeff Sovern takes another step toward effective interdiction by proposing that we flip the default of the current "don't-call" statutes. ${ }^{100}$ Instead of an opt-out system that allows telemarketing calls unless the household affirmatively opts out, Sovern suggests an opt-in system that would prohibit sales calls unless and until consumers affirmatively signaled that they wanted to receive them. Sovern persuasively argues that an opt-in default would mitigate the problem of low consumer awareness about the don't-call option. The opt-out rules give telemarketers no incentive to educate consumers about their legal options. In contrast, the opt-in rules, like other penalty defaults, place the onus on the betterinformed party and hence can have an information-forcing effect. ${ }^{101}$

These alternatives-whether they be private attempts to perfect consumer filtering (via unlisted numbers or the TPS), public attempts to perfect consumer filtering (via the TCPA or don't-call statutes), or public

98 See supra notes 53-57 and accompanying text. For a list of strategies a consumer can use to diminısh the number of telemarketing calls she receives, see Junkbusters.com, Junkbuster's Guide to Reducing Junk, at http://www.junkbusters.com/ht/en/self.html\#telemarketıng (last visıted Feb. 12, 2002). By scrolling up and down on that page, the reader can obtain comparable information about how to avoid spam and direct mail. See also Federal Communications Commission, Unwanted Telephone Marketing Calls, at http://www.fcc.gov/ccb/consumer_news/unsolıcı.html (last modıfied May 21, 2002).

99 See DiRECT MARKETING ASSOCIATION, How To Get Your Name Off Telemarkeling Lists, in CONSUMERS: A HELPFUL GUIDE, http:/www.dmaconsumers.org/offtelephonelist.html (last visited Feb. 12, 2002); Direct Marketıng Association, Privacy Promise Member Compliance Guide, at http://www.the-dma.org/library/privacy/privacypromise.shtml (last visited Feb. 12, 2002). The DMA also operates a mall preference service and an emall preference service. Direct Marketing Association, Subscribe to the DMA's Mail Preference Service, at http://www.thedma.org/preference/mpssubscription.shtml (last visited Feb. 12, 2002); DIRECT MARKETING ASSOCIATION, Email Preference Service, in CONSUMERS: A HelPFUl GUIDE, at http://www.preference.the-dma.org/products/mpssubscription.shtml (last visited Feb. 12, 2002). The Email Preference Service not only allows individual consumers to opt-out of solicitations from DMA members, but also allows web administrators to opt-out for an entire domain. See DIRECT MARKETING ASSOCIATION Email Preference Service, in CONSUMERS: A HELPFUL GUIDE, at http://www.dmaconsumers.org/emps.html (last visited Feb 12, 2002).

100 See Sovern, supra note 15, at 1101.

101 See Ian Ayres \& Robert Gertner, Strategic Contractual Inefficiency and the Optimal Choice of Legal Rules, 99 YALE L.J. 87, 106-07 (1992). 
attempts to interdict on behalf of consumers (as with the prohibition on nighttime and pre-recorded calls)-all share two basic flaws relative to our proposal. These alternatives are both under- and over-inclusive.

These policies are under-inclusive relative to our market approach. Consumers relying on the TPS, the TCPA and/or telephone company services such as Caller ID will still be subjected to unwanted intrusions. Some telemarketing companies are not bound by DMA regulations because they are not members of the organization. Moreover, a substantial proportion of the organization's membership violates its privacy guidelines $^{102}$ and the DMA appears to be making little effort to improve compliance. ${ }^{103}$ The TCPA, meanwhile, adopts a "one bite" rule that allows each telemarketing firm to call a consumer at least once. ${ }^{104}$ And even in combination, Caller ID and an unlisted number will not stop a telemarketer that purchases its calling list from a bank, health plan or utility-or any other source apart from a phonebook-from cutting short a consumer's nap.

Moreover, these "all or nothing" policies are under-inclusive relative to our proposal because some consumers may rationally prefer "all" to "nothing," but would be still better off with "sometimes." A resident who wants to facilitate communication with her friends may opt for a listed number-knowing that in doing so, she will expose herself to many unwanted telemarketing calls-when she would have preferred to facilitate non-commercial calls and literally to tax the commercial ones. ${ }^{105}$ Or a resident may rationally prefer to remain off a "don't-call" list because she values a few informative solicitations, when she would prefer even more to filter the less attractive of these calls with a pricing mechanism.

102 See Paul M. Schwartz \& Joel R. Reidenberg, Data Privacy Law 333 (1996), cıting Mary J. Culnan, Consumer Attıtudes Toward Secondary Information Use, Privacy and Name Removal: Implications for Direct Marketıng, Paper Presented at Chicago/Mrd-West Direct Marketıng Days (Jan. 20, 1993) (statıng approxımately one-half of DMA members do not use the Mall Preference Service).

103 See id. at $217,338-39$.

104 For the full list of TCPA regulations, see Junkbusters.com, U.S. Laws on Telemarketing, http://www.junkbusters.com/ht/en/fcc.html (last visited Feb. 12, 2002). A consumer successfully sued AT\&T under the TCPA for contınuing to make telemarketıng calls after he asked them to stop. $A T \& T$ Loses Suit over Telemarketing Calls, N.A.M.E.D. NEWS SERVICE (August 13, 1999), available at http://www.stopjunkcalls.com/at\&t.htm.

105 The private precaution whereby consumers "unlıst" their number also leads to inefficient over- and under-inclusion (as well as the out-of-pocket service fee) along other dimensions. Unlisted numbers are over-inclusive because they block communications that the resident would have wantedincluding non-commercial communications. Unlisted numbers make the resident less accessible not only to telemarketers but to college friends as well. In short, persons who "unlist" often opt out of too many communications relative to our market approach. And unlisted numbers are under-inclusive because they are often imperfect filters. While some telemarketers compile their call lists from telephone books (and hence do not have access to unlisted numbers) others purchase their list from banks or other retallers who have access to consumers' numbers (even if unlisted) as a precondition of doing business. See Anttelemarketer.com, Methods of Antitelemarketing, at http://www.antitelemarketer.com/index $2 \mathrm{k} 1$.htm (last visited Feb. 13, 2002). 
These various interdiction policies are also over-inclusive relative to our market approach. Many people who currently opt for "nothing" instead of "all" would be better off if they had the opportunity to say "sometimes." None of these interdiction approaches comes close to facilitating the maximum number of efficient transactions.

This problem is especially serious for the various opt-in and opt-out approaches. These approaches essentially provide that the only consumers who receive sales calls are those that derive positive utility from the average phone solicitation. But as with Gresham's law of money, bad telemarketing calls tend to drive good calls out of circulation. While consumers may value the informational content of some telemarketing calls, the relentless abuse of the bad calls lowers the value of the average and hence makes it rational for many households to say good riddance to all calls. Moreover, as we discussed at length in Part I, the inconvenience to a consumer from listening to certain telemarketing calls may be outweighed by the benefit to the telemarketer. The opt-in and opt-out approaches would block these transactions - even though, by assumption, everyone would be better off if the telemarketer could compensate the consumer for her inconvenience. "Don't-call" lists are therefore overinclusive both because they filter calls that the household would not find inconvenient and they filter calls that are inconvenient but are nonetheless socially beneficial. ${ }^{106}$ The net impact of such over-filtering is detrimental not only to consumers but also to telemarketing firms and their employees. $^{107}$

106 The private options for interdiction-ranging from unlisted numbers to caller ID to the Telezapper-suffer from analogous problems of over- and under-inclusion. They are crude devices that restrict households' ability to filter the kind of calls in which they are interested. None of the private technologies allow individuals to be compensated for their time. And since our proposal does not eliminate these pre-existing options, it would only serve to increase individual choice.

107 The DMA claims that the direct marketing industry employs more than 14.7 millon people. See Direct Marketing ASSOCIATION, 1999 ECONOMiC IMPACT: U.S. DiRECT MARketing TODAY EXECUTIVE SUMMARY (1999). However, there is reason to believe that the DMA overestimates the number of people who work in direct marketıng. Calıfornians Against Telephone Solicitation, The Great Telemarketing Lie, at http://www.stopjunkcalls.com/lie.htm (last visited Feb. 13, 2002), describes one of the reasons why estimates of the number of people who work in telemarketing are so varied and potentially misleading. Within the telemarketmn industry, telemarketıng refers to both "inbound" telemarketers, i.e., people answerng phones at customer call centers, and "outbound" telemarketers, i.e., people placing calls to consumers and businesses for advertising purposes. Since our proposal, as with most telemarketıng legislation, would affect only "outbound" telemarketers, it would impact only a percentage of what the DMA regards as the telemarketıng workforce. While requiring telemarketers to pay compensation may also dampen employment, the impact is likely not to be as great as an equilibrium where a large proportion of the potential audience opts for "don't-call" status. The impact on employment may also be dampened by the current profits that are avalable to devote toward consumer compensation under our proposed system. According to Catherine Romano, supra note 23, at 31, every dollar spent on outbound telephone marketing in 1997 resulted in an estımated $\$ 7.31$ retum on investment. Cf. Cox, supra note 64 , at 423 (noting that most telemarketing calls are from mainstream profitable busıness that do not need telemarketıng to survive). 
Our approach affords consumers both of the options available under the opt-in and opt-out schemes, plus a range of intermediate choices that make it possible to conduct most of the efficient transactions that would be obstructed by these schemes. A consumer can replicate the current default rule by setting her price at zero. She can block all future solicitations by setting an arbitrarily high price-e.g. $\$ 5,000$ per sales call-or literally declining all calls. But she can also choose a more modest price that nevertheless allows telemarketers to compensate her for the bother associated with an unsolicited solicitation.

Finally, there is a real risk that these problems of over- and underinclusion will intensify over time. The dynamic problem is that as consumers increasingly use the variety of public and private tools to make themselves unavailable to telemarketers, the industry will have perverse incentives to focus their harassing attention on the few people who fail to opt out. As with other types of visible victim precaution, opting out can impose costs on those who fail to take the precaution. ${ }^{108}$ Just as insurance markets can unravel as successive rounds of insureds opt out of the insurance pool, telemarketing pools can inefficiently unravel as successive rounds of consumers register for state "don't-call" lists or de-list their phone numbers. Perversely, opting out of the telemarketing pool can be seen as a kind of "adverse selection." Some of the people who opt out in later rounds only do so because their fellow citizens opted out early, and those who fail to opt out due to ignorance or inertia are left alone to bear the concentrated attention of the telemarketing industry.

This dynamic problem is likely to be muted under our market approach for two reasons. First, consumers who post intermediate prices are still quasi-available to the telemarketing industry (albeit for a price) and hence will dilute the industry's focus on the consumers who fail to choose an intermediate price. Second, as we will discuss more fully below, the carrot of potential compensation is more likely to overcome the problems of ignorance and inertia than the uncommodified framework that currently confronts consumers in states with "don't-call" statutes. ${ }^{109}$

In sum, our marketizing proposal is not only better than the laissezfaire system that existed for many years, it is better than the various forms

108 See Oren Bar-Gill \& Alon Harel, Crime Rates and Expected Sanctions: The Economics of Deterrence Revisited, 30 J. LEGAL STUD. 485 (2001); Ian Ayres \& Steven D. Levitt, Measuring the Positive Externalities from Unobservable Victim Precaution: An Empirical Analysis of Lojack, 113 Q. J. ECON. 43, 65-67 (1998).

109 Default choice will have an important effect on the size of this dynamic problem under either a commodified or a non-commodified system. For example, Professor Sovern's opt-in default is much more likely to depress the dynamic problem as ignorant and inert consumers will, by default, opt out of the system. See Sovern, supra note 15. As a pragmatic matter, we predict that virtually $100 \%$ of consumers in equilibrium would be inaccessible to telemarketers under Professor Sovern's proposalbecause who would want to be the only consumer (or one of very few consumers) to be subject to telemarketers' entreaties? 
of public and private interdiction and interdictory choice that have been proposed and partially implemented at the state and federal levels. Having considered the theoretical underpinnings of a market-based approach, we are now ready to provide more details of how our system would function.

\section{Implementation}

There are several reasons to focus on telemarketing-as opposed to another kind of direct marketing. ${ }^{110}$ First, sales calls are more invasive (and annoying) than spam and direct mail. ${ }^{111}$ We can at least choose at what point during the day we want to sort through our email. Second, telemarketing is the biggest business. Total expenditures by sellers and sales to consumers are larger for telemarketing than for any other kind of direct marketing. ${ }^{12}$ Third, there are fewer obstacles to the application of a market-based solution to telemarketing than to other kinds of direct marketing. As we explain in Section D, a market-based approach to direct mail would have to surmount higher First Amendment hurdles while a similar approach to spam would have to overcome more serious technological obstacles.

110 Another reason to focus on telemarketing rather than spam is because scholars have devoted much less attention to the former. The literature on solving problems associated with spam is truly voluminous. See, e.g., Lorrie Faith Cranor \& Brian A. LaMacchı, Spam!, 41 CoMM. ACM 74, 80-83 (1998); Credence L. Fogo, The Postman Always Rings 4,000 Times: New Approaches To Curb Spam, 18 J. MARSHALl J. COMPUTER \& INFO. L. 915 (2000); Hawley, supra note 11; Jeffrey L. Kosiba, Comment, Legal Relief from Spam-Induced Internet Indigestion, 25 U. DAYTON L. REV. 187 (1999); Sımmons, supra note 16; David E. Sorkın, Unsolicited Commercial Email and the Telephone Consumer Protection Act of 1991, 45 BUFF. L. REV. 1001 (1997).

111 Rosenfield, supra note 28 , at 15-16, relates the following anecdote:

Telemarketing is indeed the medium everyone loves to hate, and hates to love. Which is why I am utterly intrigued by a malling I just received from National Glaucoma Research. Its basic pitch is a promise not to call me on the phone!

The envelope copy, in faux-hand-writing, says: "I didn't want to bother you over the phone. I hope I made the right decision."

Above the salutation, the headline reads "The 'experts' say I'm wastıng my tıme writıng, that only by calling you at home can I hope to get your help..."

"Obviously," the letter contınues, "I think those 'experts' are wrong."

"Because if you're at all like me, and $I$ have reason to believe you are ..."

“... You're sick and tired of people calling you at home, at the most inconvenient tımes, intruding into your life!"

"But when I told the 'experts' NO, I couldn't do that to you, they said I'd regret It. I hope they're wrong, because I really need your help."

Wow! I don't know if this is blackmail or brillance or both, but it sure got my attention! What cunningly manipulative copy ....

112 DiRECT MARKETING ASSOCIATION, 2000 ECONOMIC IMPACT, supro note 25, at 15; see also American Teleservices Association, supra note 56 ("Despite its emergence as a marketing and purchasing tool, the Internet still lags behind the telephone in consumer purchases. According to a consumer study conducted on behalf of the American Teleservices Association (ATA), $45 \%$ of Americans have initiated a purchase via telephone in the past year - compared with $37 \%$ who have initiated a purchase over the Internet in the same period."). 


\section{A. Our Preferred Approach-Authorized Intermediation}

Our basic mechanism would only require a very slight amendment to the FTC's current "don't-call" proposal. Under the FTC's proposal, as under its state counterparts, telemarketers remain free to contact registered households so long as the household has expressly authorized calls from that "specific seller." 113 But it would be possible to expand the definition of "specific seller" to include intermediaries who had been authorized to connect calls that meet pre-specified household compensation (and potentially non-compensation) prerequisites. Specifically, the definitions in Section 310.2(x) might include an additional sentence:

A 'specific seller or charitable organization' for purposes of $\S$ 310.4 (b)(1)(iii) shall include intermediaries who are authorized to connect calls that meet pre-specified household prerequisites.

It is our claim that adding these twenty-four words can radically redeem the telemarketing industry. Telemarketers who wish to reach registered "don't-call" households will have to connect their calls using an "authorized intermediary." Authorized intermediation works in tandem with the "don't-call" proposal. The "don't-call" option allows households to reclaim their rightful property interest in privacy, while the intermediation option allows them to alienate their privacy at the price they desire. ${ }^{114}$

Authorized intermediation also simplifies the government's regulatory task. Instead of registering a price with the government, the household simply registers its name on the don't-call list and simultaneously authorizes any intermediaries to connect calls that meet the household's prerequisites. Instead of facing difficult implementation issues, the government can simply let competition among potential intermediaries determine the categories that maximize household demand. The government need not set a default level of compensation or decide how finely grained the pricing options for different times need to be; rather, the government can let the intermediation market decide.

The intermediaries might even vie for developing content-based filters (in addition to compensation pre-requisites). Some households might only want calls concerning cooking or sports, others might only want calls pre-approved by Good Housekeeping, or Jerry Falwell or Ralph

113 Telemarketıng Sales Rule, supra note 10.

114 While other academics have considered the utility of using price to internahize the externalızed cost problem of direct marketıng, see for example, Petty, supra note 4, at 3, this Artıcle is the first to suggest the extent to which the compensation market could be privatized through authorized intermediation. 
Nader. And there is good reason to think that the intermediation market would have several competitors vying for household business. While local phone companies - as existing intermediaries-will probably be important players in such a market, long distance carriers or even newly created intermediation specialists (such as Good Housekeeping) are likely to compete to provide this service for a fee. Intermediation would of course not be without cost, but a competitive market for intermediation services is likely to sort out whether the telemarketers or customers would bear the cost of intermediation. ${ }^{115}$

And intermediaries have great incentives to educate consumers about the possibility of compensated calling. We even imagine that intermediaries are likely to be the first telemarketers to voluntarily compensate as a means of "seeding" consumer demand for their service. Imagine picking up your phone and hearing: "This is a compensated call from Verizon. You will receive $\$ x x$ simply for listening." Next time a telemarketer calls you without offering to pay, ask them why not?

Under an authorized intermediation system, telemarketers who wanted to reach households that had registered on the "don't-call" list would need to call from an intermediary with whom the household had registered using what we call an "outgoing 1-900 number." With traditional "incoming 1-900 numbers," a payment from the caller to the recipient is triggered by a call into a recipient's 1-900 number. Outgoing 1-900 numbers work the same way except that the payment is triggered by calls made from a 1-900 number. When a telemarketer called a residence using an outgoing 1-900 number, the local phone company would automatically credit the residence's phone bill for an amount chosen by the resident when giving its authorization to the intermediary. Just as the resident pays a per-minute charge set by the recipient when she calls the psychic hotline, the psychic hotline would pay a per-minute charge chosen by the recipient if it chooses to drum up business by calling the resident. Notice the symmetry: if commercial establishments can demand that citizens pay them when the citizens call, we propose that citizens be able to demand that commercial establishments pay citizens when the commercial establishments call.

For concreteness, we would piggyback on many of the contours of the current "don't-call" statutes. Thus, for example, we would exempt from this requirement telemarketing calls made by non-profits and polling organizations. ${ }^{116}$ Indeed, it is possible to implement this system without

115 We predict the bulk of the charges would be borne by telemarketers because intermediaries competing for the consent of households that had registered for "don't-call" status would hikely compete by offering lower intermediation prices.

116 Connecticut, for example, exempts eight different types of transactions: calls made with the consumer's express permission; calls made by a non-profit organization; calls made in response to 
changing the look or feel of the "don't-call" registration process by requiring intermediaries to keep sufficient record of "express authorization"-as is currently contemplated with the "specific-seller" exception.

Residences would retain the current "no calls" option by simply registering for the list without granting any intermediary (or any specific sellers) authorization. But others would reclaim their privacy right by registering for the "don't-call" list and simultaneously (or subsequently) authorizing an intermediary to connect calls for different prices per minute for daytime, evening and nighttime calls (possibly specifying different prices for weekends). The government would not need to decide how nuanced the pricing options need to be-any more than it needs to regulate the intricacies of cellphone pricing plans. Let the intermediation market decide.

If a household failed to register, the default compensation they would receive would be the same as now-nothing, and the default prohibition against late night calls would remain in place unless the household opted for a different price (including potentially a zero price). We would, however, lift completely the prohibition against pre-recorded calls. But we would require-as discussed above - standardized, initial disclosure that a call is an unsolicited telemarketing call and the amount of per-minute compensation.

The telemarketers would have access to the "don't-call" list and would know that they could only contact people on the list by piggybacking on the intermediaries' express authorization-which would in all likelihood be conditioned on the payment of compensation (that the household would pre-specify with the intermediary). Either the telemarketer or the household would have the option of terminating any individual call. Partial minutes would be rounded up to determine the total time of the call. ${ }^{117}$

The intermediaries could also play a roll in verifying to the consumer that a particular telemarketing call was in fact paying compensation. At the same time that a household registered its price with the intermediary, the household could list a 3-digit pin code (or possibly choose from fifty sound clips). The outgoing 1-900 number software of the intermediary

a visit by the consumer to the caller's place of busıness; calls made in response to a consumer's express request to be called; calls made to collect on a debt; calls made to an existing customer, unless they have requested not to be called; calls made by a telephone company in connection with creating or distributing telephone directories; and calls made by any person creating or distributing telephone directories on a telephone company's behalf. In addition, new busınesses may contact consumers on the state "don't-call" list, but are stıll governed by restrictions on callıng hours and the use of recorded messages. CONN. GEN. STAT. ANN. § 42-288a (West Supp. 2002).

117 This rule dampens incentives for telemarketer shenanigans and compensates the recipient for the time and inconvenience of going over and picking up the phone. 
could then be set up to announce the PIN code at the start of the call (outside of the telemarketer's earshot) so that the resident would immediately know that the call was a valid (i.e., compensating) telemarketing call. People receiving a telemarketing pitch that was not preceded by the telltale tone or PIN would have immediate notice of a violation. ${ }^{118}$ Granting citizens a private bounty for identifying violators could maintain the viability of the legal mandates. ${ }^{119}$

These few paragraphs give the basics of a workable market system. This is a system that doesn't require a technological breakthrough to implement. And while for simplicity we have cleaved to many of the regulatory choices already embodied in "don't-call" statutes, there are many regulatory details that deserve further elaboration. We turn our attention to these details in the remainder of this Section.

\section{B. The Pricing Mechanism}

As with the design of auctions, there are a myriad of alternative rules that can equilibrate toward a market price. Here we discuss two crucial dimensions-who offers the initial price; and what is the default price.

\section{Who Should Offer the Price}

While our preferred approach allows consumers to set the price they demand as compensation (when they authorize the intermediary), it would also be possible to establish a regime where the telemarketers would choose the price they were willing to offer. ${ }^{120}$ Indeed, our forgoing discussion of requiring standardized, initial disclosure amounts to just such a system. ${ }^{121}$ Imagine, for example, that telemarketers were merely required to disclose at the outset of the pre-recorded message, "The telemarketer

118 Another problem with direct marketıng is the fact that parties engaged in solicitation have an incentive to mislead consumers, to mislabel their product, and to disguise the nature of their communication with consumers. But as discussed above, this is solved through standardized, initial labelıng - the distinctive tone or stıcker or subject heading or phrase-and by addressing the consumer usıng a unique username unknown to the telemarketer.

119 The effectiveness of private enforcement may be seen from the story of a consumer who successfully sued AT\&T under the TCPA for contınuing to make telemarketıng calls after he asked them to stop. See AT\&T Loses Suit over Telemarketing Calls, supra note 104. Private Citizen reports that its customers have collected over $\$ 1$ million since 1996 in damages against telemarketers who called Private Citizen members. Private Citizen, Homepage, at www.privatecitizen.com (last visited Feb. 13, 2002). See also Cox, supra note 64, at $412-13$ (discussing Szefczek v. Hillsborough Beacon, 668 A.2d 1099 (N.J. Super. Ct. Law Div. 1995)).

120 It would also be possible to have public officials choose the price. See Petty, supra note 4 , at 46 ("regulators should conduct rate heanngs to determıne how much consumers would like marketers to be charged on a per minute basis for the right to make such calls.").

121 See supra Part II.A. 
offers to pay you \$xx a minute to listen to the following call." This regime would effectively give the telemarketers the power to set the initial price.

Forcing telemarketers to state their offered compensation at the beginning of the call facilitates consumer filtering of unwanted calls, because consumers can simply hang up on low-ball offers. But this hangup strategy still forces consumers to go over and pick up the phone and repeatedly choose. We could do better by forcing the standardized disclosure to come even earlier-by including information about the price the telemarketer offers in the telemarketer's own phone number. The 1900 numbers used by telemarketers could include two or three-digits expressing how many cents per minute they were offering to consumers. The telemarketers would still be free to offer any amount that they wished, but Caller ID systems (or new services offered by the local phone company or government itself) could automatically block any calls that fell below the consumer's reservation price. ${ }^{122}$

Some might worry that a telemarketer-choice system would be useless since telemarketers would cling to their present practice of offering no compensation. But this system would differ importantly from the status quo because households would know that telemarketers had a practical option of compensating listeners. We predict that telemarketers under this system of disclosure would be forced by competition with other telemarketers to offer compensation.

Indeed, far from the status quo, a telemarketer-choice regime with automated filtering by households is likely to be largely equivalent to a household-choice regime with automated filtering by telemarketers. ${ }^{123}$ To the extent that the regimes differ, we prefer the household-choice system because it is less cumbersome-producing fewer filtering costs and imposing the costs on the telemarketers instead of the consumer. ${ }^{124}$

We should note in closing that neither consumers nor telemarketers have the incentive to choose the socially efficient price. Ideally, we would

122 This telemarketer-choice cum consumer filter is analogous to a policy that Larry Lessig has suggested to control spam. See Lawrence Lessig, What Things Regulate Speech: CDA 2.0 vs. Filtering, 38 JURIMETRICS J. 629 (1998).

123 Indeed, instead of prohibiting telemarketers from calling any household whose price was above the telemarketers' willingness to pay, the state could offer a filtering service to block, on households' behalf, any call that did not offer sufficient compensation. Under this system, telemarketers could try to call anyone they wanted (as long as they electronically disclosed their offered compensation), but they would only be able to get through when their offered compensation exceeded the household's demand.

Households somewhat perversely might be better off under a telemarketer-choice system with household filterıng than under a household-choice system with telemarketer filtering. If the telemarketer is kept unınformed about the size of the household filter (1.e., the minımum compensation that the household demands), then the household might receive initial compensation offers that exceed their reservation price.

124 A telemarketer choice might reduce the telemarketers' incentive to adequately research whether consumers would be interested in the call. 
like the price chooser to pick her reservation price, so that the offeree would have an incentive to accept all socially beneficial offers. Unfortunately, a hyper-rational chooser may have an incentive to set the price in a more self-interested manner. For example, a resident may not be content with setting a price to compensate for the telemarketing inconvenience; he or she may instead try to profit from telemarketing by charging a supra-competitive price-one that deters some socially beneficial calls. This theoretical concern should not detain us long. We face analogous concerns in many other contexts without resorting to price regulation or abandoning the market altogether. There are enough consumers and telemarketers to trust the competitive process to produce an equilibrium that will be massively more efficient than either laissez-faire telemarketing or the interdictory alternatives discussed above.

\section{Default Choice}

While hyper-rational residents may, as a theoretical matter, have incentives to set prices that are too high, we are more concerned about the much more real problems of ignorance and inertia. An important lesson from the state experience with "don't-call" statutes is that it is difficult to educate and motivate residents to act. ${ }^{125}$ Quick-do you know whether your state has a "don't call" statute? ${ }^{126}$ And if it does, have you failed to register simply because of inertia? As in other contexts, ${ }^{127}$ the default price demanded when households are silent is likely to have a large impact on the ultimate equilibrium. Just as Sovern proposed an opt-in default, which presumptively banned telemarketing calls unless a household registered on a "please-call" list, ${ }^{128}$ we are deeply attracted to presuming some level of compensation that would govern all households unless the household affirmatively moved to increase or decrease the default.

Default prices that are either substantially higher or lower than the price that households would normally choose could be considered "penalty" (or "information forcing") defaults that would give households an incentive to affirmatively opt for their preferred prices. But in this setting the rationale for "penalty" defaults is largely lacking. Penalty defaults are most often used when lawmakers want to force the disclosure

125 Cox, supra note 64 , at 424 observes, "The trouble [with existing regulations] is twofold. First, most people are uninformed. They are unaware of 'do-not-call' lists and so do not know how to protect themselves."

126 Alaska, Alabama, Arkansas, Calıformı, Colorado, Connecticut, Flonda, Georgıa, Idaho, Indıana, Kentucky, Loussıana, Maine, Mıssourı, Montana, New York, Texas, Tennessee, Wisconsın and Wyoming currently have "don't-call" lists. Michigan, New Jersey, Pennsylvania and Ohio have pending legislation that would create "don't-call" lists. See supra note 5.

127 See Ian Ayres \& Robert Gertner, Filling Gaps in Incomplete Contracts: An Economic Theory of Defaull Rules, 99 YALE L.J. 87 (1989).

128 See Sovern, supra note 15. 
of private information that sometimes occur when people opt out of the rule. But here, the central problem isn't that households have private information that we want them to reveal by contracting around the default. The central problem is that households may not know that they have the option to be compensated and to control the amount of compensation.

Penalty defaults that are set too high (say, $\$ 10$ per minute) or too low (say, $\$ 0$ per minute) are in fact less likely to inform residents that compensation is possible because neither default is likely to give rise to any compensation for the silent majority. Under a $\$ 10$ default, no telemarketers will call, and under a $\$ 0$ default, none of the calls will be compensated. In the telemarketing context, the beauty of setting a modest, but positive default price is that it will quickly inform residents about the new potential for compensation. Each month's phone bill will disclose the telemarketing credits that the household receives (and might disclose how the consumer could vary the default price).

We are particularly attracted to using the federally mandated minimum wage as a focal point to measure how much people should value their time. On a per-minute basis, the minimum wage currently amounts to about nine cents. ${ }^{129}$ If workers deserve at least nine cents per minute, then residents deserve at least this amount to help a for-profit enterprise market its product. And make no mistake, the person who takes time to listen to a marketing pitch is helping to market a product. This measure might even be taken as a rough measure of what a majoritarian default would be. ${ }^{130}$

In the end, however, we have opted for the status-quo defaults, which effectively set a zero price for daytime calls and an infinite price for nighttime calls. These extreme status quo defaults—as argued above-are less likely to provide households with the information from actual phone credits about the new opportunities for compensation. But if the status quo defaults are combined with our proposed requirement that telemarketing calls begin with a disclosure of the offered compensation, we are confident that most Americans will soon become very aware that their attention has a market value. Cleaving to the status quo is also likely to ease the transition for telemarketing companies that will need time to adjust to the new regime.

129 Federal minımum wage is currently $\$ 5.15$ per hour. See United States Department of Labor, Wages, Minimum Wage, at http://www.dol.gov/dol/toplc/wages/mınımumwage.htm (last modified Feb. 14, 2002). On a per minute basis, this amounts to $\$ 0.0858$.

130 Alternatively, one could more directly try to estimate what the majority of residences would want by takıng a survey of consumer preferences. As is often the case, much would turn on how the questions were phrased. Our informal surveys to an admittedly non-random sample found massively different answers if we simply posed the question in terms of dollars per minute versus cents per minute. And there are even more vexing questions about the degree to which more nuanced preferences concernıng the pricıng of different tımes or types of telemarketıng should be elıcited. 
Setting a non-zero default might also increase the government's enforcement burden. Keeping the status quo defaults, by contrast, takes the government out of setting literal transfer prices. When the default price is zero, no transfer is required. And when the price is infinity (as with nighttime or fax or cellphone calls), no transfer is required because no calls are allowed. Indeed, our proposed system of "authorized intermediation" in a sense privatizes the default choice. The intermediary-like Priceline.com-can recommend reasonable prices that are likely to get some takers. Moreover, competition among the authorized intermediaries can take on the myriad pricing questions-such as whether to offer a two-part pricing system, a simpler price-per-minute system, or a finely grained system in which price could be coordinated on virtually any aspect of the pitch.

\section{Exempt Solicitations}

Just as the current "don't-call" statutes prohibit residents from blocking particular types of solicitations, our market proposal would prohibit consumers from demanding compensation for certain calls. ${ }^{131}$ Telemarketers making calls that fit within an existing exemption could not be required to use an "outgoing 1-900 number" to initiate the calls. The "authorized intermediation" is a way of authorizing calls that would otherwise be blocked by the "don't-call" registration. It is a one-way ratchet. It does not provide a means of blocking calls that would otherwise have been exempt.

There are two basic rationales for the existing exemptions, which we term "positive externalities" and "consumer consent." The latter category includes situations in which the consumer has expressly or implicitly consented to waive compensation. The former category concerns calls for which there are thought to be positive third-party externalities to the call that override the consumer's interest in being left alone.

\section{Positive Externalities: Charities, Polling and Politics}

While positive externalities are traditionally a perfectly respectable rationale for mandatory rules, ${ }^{132}$ there are important limits to what these mandatory exemptions can accomplish-because households retain the right to hang up. As discussed above, the strategies that households adopt to avoid phone solicitations (such as taking an unlisted number) can themselves produce negative externalities that must be weighed against the

131 In terms of contract theory, the mandatory price for these calls would be zero with no option of opting out.

132 See Ayres \& Gertner, supra note 127. 
third-party benefits. While we might want to prohibit compensation for charitable calls in a world where households could not hang up or de-list their numbers, we might not want to ban compensation in a world where these tactics are allowed.

Even if the law exempts particular classes of calls from offering compensation, it is less clear whether they should also be exempt from the same kinds of standardized, initial disclosure that are required of other telephone solicitations. Indeed, there turn out to be three separate questions: which types of telemarketing should be implicitly subsidized; how big should the subsidy be; and who should pay the subsidy?

The traditional answer to the first question is that charitable and polling solicitations produce sufficient third-party benefits to be exempt from telemarketing restraints. We shall devote most of our attention to evaluating this traditional viewpoint. But reconceiving the issues in terms of implicit subsidies allows us to disentangle the other two questions.

Exempting telephone solicitors from a disclosure requirement is a separate and additional subsidy distinct from the exemption from paying compensation. For example, are the social benefits from charitable solicitations sufficiently great to warrant hoodwinking listeners into initiating conversations that they would have preferred not having? To our minds, while there is a (contestable) case for the compensation subsidy, promoting charitable contributions by facilitating semi-deceptive solicitation practices, which make it more difficult for households to maintain telephonic privacy, is untenable.

Recharacterizing the exemptions as implicit subsidies also allows us to ask the incidence question about who should bear the cost of the subsidy. When we see charitable solicitations in the all-or-nothing terms of the current "don't-call" statutes, it seems clear that households must bear the inconvenience of charitable exemptions. But under our market proposal, where residents post prices, it becomes possible for the government to bear the cost of exempting charities (or survey organizations) from the duty of paying compensation. If the government feels that it is socially beneficial for charities to be able to solicit without paying compensation, the government is well placed to pay the compensation on the charities' behalf so that the costs of solicitation will be borne by the public more generally instead of disproportionately by those unlucky people who are called or solicited disproportionately. After all, the government subsidizes charities through the tax code by effectively making a co-contribution; it might find it worthwhile to subsidize charitable solicitations as well by picking up part of the cost of soliciting. Indeed, once we conceive of residents as having an alienable entitlement to 
sell their attention, the government's exemption of particular types of telephone solicitation starts looking like an uncompensated taking. ${ }^{133}$

In sum, there is a strong case for maintaining a duty to disclose on all mass telephone solicitations and at least an argument for maintaining the duty to compensate (but having government reimburse the solicitors that it deems worthy). But we do not propose to tilt all possible windmills in this Article. Instead, we cleave largely to the exemptions that tend to appear in the current "don't-call" statutes concerning non-profit charitable and political organizations as well as polling-and propose extending them to exemptions from a duty to compensate as well.

The core classes of exemptions which are at least arguably based on third-party benefits are solicitations by charities, political groups and polling organizations. The idea here is that charitable contributions further more general public interests and that political communications help secure better government for all. And while political polling is sometimes decried, ${ }^{134}$ opinion polls may at times provide positive externalities---so that we learn what we collectively think about an issue or how we in aggregate behave. ${ }^{135}$ The Connecticut "don't-call" statute, for example, exempts not only charitable solicitations, but all calls made "for a noncommercial purpose, such as a poll or survey."136 Likewise, the TCPA's definition of a telephone solicitation expressly excludes calls from taxexempt, non-profit organizations. ${ }^{137}$

There is some evidence that the general public finds these types of calls less annoying than commercial solicitations. ${ }^{138}$ As summarized in

133 We nevertheless rush to emphasize that we do not believe this would make out an actionable claim under the Constitution's Takıngs Clause. For a good general discussion of the jurisprudence relating to the Takıngs Clause, see BRUCE ACKERMAN, PRIVATE PROPERTY AND THE CONSTITUTION, chs. 2, 4 (1977).

134 See Partnership for a Poll-Free America, supra note 36.

135 Connecticut also exempts calls by telephone companies for the purpose of eliciting information to construct telephone books. These "white pages" surveys produce the kind of positive externality effects that analogously might justify a compensation exemption. See CONN. GEN. STAT. ANN. § 42-288a(e)(2) (West Supp. 2002).

136 Department of Consumer Protection, State of Connecticut, DCP Telemarketing No Call List, at http://www.state.ct.us/dcp/nocall.htm (last visited March 2, 2002). We think this wording is slightly infelicitous. Many surveys related to consumer marketing are distınctly made for a commercial purpose, and in a world with "push polls" one could imagine surveys that were really disguised advertısements ("Did you know that Sears was having a sale today?"). Moreover, the statute never addresses the use of telemarketıng to convey information rather than to elıcit it. Political communication is decidedly a two-way street and exemptions should expressly include uses of the telephone to disseminate the news. We wouldn't want a telemarketıng law that stopped Paul Revere.

137 See 47 U.S.C. $\$ 227(\mathrm{a})(3)$ (2001). Cain, supra note 60 , at 649 n.59, writes, "The exemption for non-profit organizations are [sic] dictated by the First Amendment decisions by the Supreme Court that give charitable solicitors greater protection than commercial speech under the compelling interest standard." See generally Nadel, supra note 15, at 108-09 (discussing the definition of an unsolicited telemarketıng call).

138 One must be concemed, however, that people who were willing to take part in these surveys were not representatıve of the larger public overall. 
Table 1, the Field Research Report found that people were three times more likely to report that they "did not mind" charitable solicitations than sales calls and five times more likely not to mind opinion polls. ${ }^{139}$ And the House of Representatives Report, prepared in conjunction with passage of the TCPA, cites data from the National Association of Consumer Agency Administrators indicating that the vast majority (ranging from $80 \%$ to $99 \%$ ) of complaints in the nine states surveyed were about "commercial" (as opposed to "charitable") calls. ${ }^{140}$

Table 1. Public Reactions to Different Types of Phone Solicitations (Percent of Responses)

\begin{tabular}{|l||c|c|c|c|}
\hline Reaction & $\begin{array}{c}\text { Sales } \\
\text { Calls }\end{array}$ & $\begin{array}{c}\text { Charitable } \\
\text { Solicitation }\end{array}$ & $\begin{array}{c}\text { Political } \\
\text { Solicitation }\end{array}$ & $\begin{array}{c}\text { Opinion } \\
\text { Poll }\end{array}$ \\
\hline \hline Did not mind & 9.1 & 27.1 & 43.4 & 50.2 \\
\hline Liked & 0.1 & 0.2 & 1.7 & 3.7 \\
\hline
\end{tabular}

There are nevertheless reasons to question the utility of these exemptions. While more respondents minded sales calls than minded charitable, political and survey calls, Table 1 shows that the latter "public interest" calls still bothered a large percentage of survey participants. A clear majority did mind both charitable and political solicitations, while nearly half objected to opinion polls. Virtually no one reported liking these calls. There are also concerns that both charities and political organizations are making growing numbers of unsolicited calls, creating an overfishing problem. ${ }^{141}$ The advent of aggressive political "push polls" and professional donation solicitors-who will gladly troll the phone book on behalf of any policeman's benevolent association that is willing to pay their fee-has degraded the appearance of public interest and contributed to listener overload. ${ }^{142}$ In addition to the households' disutility, the social

139 Field Research Corp., supra note 15.

140 H.R. REP. No. 102-317, at 5 (1991).

141 American Teleservices Association, Nearly 60\% of Americans Received One or More Campaign-Related Phone Calls During the 2000 Election Cycle, at http://www.ataconnect.org/ htdocs/consinfo/consumer_study_march-feb01.htm (last visited Feb.14, 2002). The American Teleservices Association sponsored two telephone surveys on February 16-18 and March 2-4, 2001 of 1,000 consumers about their use of telephones, the Internet and related services. The research was conducted by Market Facts, Inc. See American Teleservices Association, Telephone Still Favored Purchasing Channel, at http://www.ataconnect.org/htdocs/consinfo/consumer_study_marchfeb01.htm\#telephone (last visited Feb. 14, 2002).

142 Some charities also add to the commercial abuse by selling to commercial telemarketers the names and phone numbers of their contributors. See Tom Mabe, Did You Know...? Revenge on Telemarketers, at http://www.tommabe.com/facts.php (last visited Feb. 14, 2002). Indeed, some charitıes generate substantial revenues by selling phone lists of contributors-so if our market approach dimınıshed the size of the telemarketıng industry, it might indirectly harm even some exempt charities. 
utility of calls soliciting charitable donations is increasingly contestable given the small proportion of total revenues that is made available for the charity itself. ${ }^{143}$

We are attracted to an intermediate solution: giving households the option of seeking compensation from any of these traditionally exempt groups but capping the maximum amount of compensation at the rate the speaker is being paid. If the speaker is working gratis for a grassroots political campaign, then the households could demand nothing. But if the speaker is being paid minimum wage to conduct a push poll for Bloomberg, or for soliciting contributions to the local dog shelter, we see a strong case for allowing households to seek the same amount to have to listen to the message. Of course households would not be required to seek this amount, but allowing households to charge a modest fee would likely reduce the worst excesses that are beginning to occur today and possibly increase households' receptiveness to a broader range of solicitations. ${ }^{144}$

We are not, however, willing to incur the wrath of the entire eleemosynary lobby and so we recommend that charities, political groups and polling organizations be completely exempt from the duty to compensate. As explained below, this greatly reduces constitutional concerns with our proposal. It also avoids the perverse possibility that people might become less inclined to participate in public spirited events if they gained the opportunity of being compensated. ${ }^{145}$ There is still a limit to our philanthropy toward philanthropies. We would not allow exempted organizations to take advantage of pre-recorded solicitations unless they paid the amounts requested by individual households. Exempting nonprofits from the duty to compensate listeners and simultaneously reducing

143 On average, approximately one-quarter to one-thırd of what you donate as a result of a telemarketıng call will actually get to the charity on whose behalf the solicitation is made. The telemarketıng company hired to make the call gets the rest. See Attomey General of Ohı, Take Time to Give to Charity, at http://www.ag.state.oh.us/civilrts/columns/givewise.htm (last modified Dec. 6, 1996) (stating that charities recelve, on average, $25 \%$ of the donated amount); Fran Silverman, Worrisome Hang-Ups: Charities Fear Telemarketing Law Will Curb Giving, HARTFORD COURANT, Jan. 5, 2001, at E1 (quoting Daniel Borochoof, president of the Amencan Institute of Philanthropy: "[Making a chantable donation in response to a phone solicitation] is not a very effective way of giving away your money. There is a lot of waste ... . On average, only about one-third of the money raised goes to the charity."); Mabe, supra note 142 (statıng that charıties receive on average $24 \%$ of the donated amount).

144 Interestingly, the proposed FTC rule adopts a similar intermediate position by allowing residents to block charıtable solıcitations made by for-profit intermedianes. See Telemarketıng Sales Rule, supra note 10. The FTC's power to regulate these solicitations was created by passage of the USA Patnot Act, Pub. L. No. $107.56 \$ 1001,115$ Stat 272 (2001), passed in the aftermath of the September 11 th attack. The act expands the definition of "telemarketıng" to include solicitations of "a chantable contribution, donation, or gift of money or any other thing of value." Id.

145 There are reports that blood donations have declined when blood banks started payıng for some of their blood. See Richard M. Titmuss, THE GifT RELATIONSHIP: From Human BlOOD to SOCIAL POLICY 41-70 (1971). 
their cost of speaking would likely spur a feeding frenzy that could be worse than the status quo.

A final question is whether there are any other types of calls that deserve the implicit subsidy of exemption from required compensation. Some people have proposed that small businesses should qualify-because they are especially needful or are the well-spring of economic growth. ${ }^{146}$ Meanwhile, the Connecticut "don't-call" statute exempts calls from new businesses (defined as solicitors for whom "a period of less than one year has passed since such telephone solicitor first began doing business in this state"). ${ }^{147}$ We respectfully dissent. We see no reason why the benefits of creating or expanding small or new businesses should be paid for with domestic privacy. If the commercial solicitations of these businesses are worthy of subsidization, we say let the general fisc bear the cost.

\section{Policing "Consumer Consent"}

The second group of exempt solicitations stands on a very different footing. The purpose of our market approach is to force "unsolicited" callers to compensate listeners for their time-giving the listener an opportunity to consent in advance and thereby solicit the intrusion on her time. But it is perfectly reasonable to provide exemptions from compensation where the listener has already explicitly or implicitly consented to the call -and so waived the compensation requirement. Indeed, our entire "authorized intermediation" system relies on the revealed preference of households to signal that compensated telemarketing is a welcome intrusion on their privacy.

But the "express authorization" exemption can be abused by telemarketers who will try to avoid the compensation requirement by manipulating consumers to give less than informed consent. The law will have to police difficult issues concerning the quality, scope, and durability of consent. Luckily, many of these issues have already been under discussion for several years with regard to parallel issues on the Internet. ${ }^{148}$

146 It is a political truism that small businesses are responsible for the creation of a large number of the jobs in this country. For example, the 2000 Republican Party Platform states: "Small businesses create most of the new jobs and keep this country a land of opportunity." See Malla Pollack, Opt-In Government: Using the Internet To Empower Choice-Privacy Application, 50 CATH. U. L. REV. 653, 669 n.72 (2001) (citing simılar passages in both the Republican and Democratic party platforms).

147 ConN. Gen. Stat. ANN. $§ 42-288 \mathrm{a}$ (c)(1)(B) (West Supp. 2002).

148 Various industry "best-practice" proposals encourage retallers to obtain consumers' consent prior to sendıng email advertısements. See, e.g., T. Gavin et al., How To Advertise Responsibly Using Email and Newsgroups or How NOT To MAKE ENEMIES FAST!, at http://www.1etf.org/rfc/rfc3098.txt (last modified Apr. 2001). One proposal to regulate "spam" under federal law would simply add "electronic mall address" to the existing legislation prohibiting the sending of advertısing to fax machines. See H.R. 1748, 10Sth Cong. (1997). The legislation would require either (1) a pre-existing and ongoing business or personal relationship between the mailer and 
We suggest that consent be unbundled and non-durable. A potential, existing or past consumer should have to affirmatively waive the right to be solicited to buy additional products or services. The waiver should be unbundled from other transactions and waiver should require some affirmative act (as opposed to passively accepting a default waiver). ${ }^{149}$ And as a prophylactic, we suggest that the waiver only be effective for some limited period-perhaps two years. The business's right to solicit without paying compensation should not be assignable to other companies-otherwise, waiving compensation from one business could effectively provide a waiver to all businesses. Assignable rights create too large a temptation for firms to hoodwink consumers into granting overly broad consent. A household that wanted this result could more easily just eliminate the general compensation it was seeking.

The "don't-call" statutes have made a first attempt at policing household consent. The Connecticut statute, for example, exempts four classes of calls where consent is express or presumed. To wit, calls made: with the "consumer's prior express written or verbal permission;" in response to a consumer's visit to an establishment with a "fixed location;" in connection with an existing debt or contract that has not been paid or performed; and "to an existing customer." 150

We find no fault with the first or the third exemption. Express consent is the gold standard (if based on a sufficiently affirmative and knowing act) and it should be presumed that borrowers consent to allow uncompensated calls regarding collection of a debt that is in arrears. The second and the fourth exemptions are, however, more problematic. We do not believe that merely visiting a car dealership should be seen as implicitly consenting to waive your domestic privacy. Let the dealership obtain a more affirmative waiver, if it wants to follow up. And the existing customer exemption is overbroad. We agree that businesses should be able to call (without compensating) about issues arising out of the performance of an ongoing contract- so that a car repair place could call to tell a customer she really needs a new transmission. We might also presume that businesses could call to remind customers about renewing periodic services-so your dentist or a lawn-service could call to tell you it was time for your yearly checkup. But we do not think that businesses should be given carte blanche to solicit existing customers to purchase new kinds of products or services. The bank that manages my checking account should not be given authority to pitch a home-mortgage or life insurance to me. The existing customer exemption creates a perverse incentive by

\footnotetext{
the recipient or (2) the recipient's express permission before a commercial email could be sent. See id.

149 However, we would allow the seller to warn the consumer one time that the consumer was about to miss an important opportunity.

150 See CONN. GEN. STAT. ANN. § 42-288a(a)(6)(a) (West Supp. 2002).
} 
banks to become the intermediaries for a host of unrelated products. After all, who is going to want to refuse to listen when their bank calls? Unfortunately, banks are already exploiting this loophole in Connecticut. $^{151}$

\section{Constitutionality}

Our proposal for facilitating compensated telemarketing calls via authorized intermediation would withstand any free speech challenge. American courts have been incredibly amenable to laws regulating telephone calls-and commercial telemarketing in particular. ${ }^{152}$ Indeed, there is a strong argument that because the all-or-nothing "don't-call" regulations already in place in several states and proposed by the FTC are constitutional, our proposal which grants individuals greater freedom is $a$ fortiori constitutional.

The twenty-four words that we have suggested adding to the FTC's don't-call regulation merely grant non-governmental agents-the households and their agents, the intermediaries--the right to connect a subset of potential calls that the households want to hear. Our "authorized intermediation" program, thus, does not involve the government in content based regulation but allows private listeners and private intermediaries to devise content-based filters (if they so desire)-including content based prices for different types of telemarketing messages.

There are at least three lines of jurisprudence that render courts sympathetic to telephone-related regulations. First, courts are more receptive to restrictions on point-to-point media, such as mail and phone communications, than broadcast media, such as radio and television, because restrictions on the former-as opposed to the latter-need not prevent dissemination of messages to willing recipients. ${ }^{153}$ Second, the more intrusive a mode of communication, the more authority the government has to regulate it. ${ }^{154}$ The Supreme Court has held that aural communications are more intrusive than visual communications because

151 Interview with Don Barkin, Adjunct Professor, Wesleyan Unıversity (Jan. 26, 2002).

152 According to Cox, supra note 64, at 419, nearly every American court to review a telemarketing regulation has upheld it. The same authority observes that the District Court of New Jersey is the only jurisdiction which currently has valid precedent striking down telemarketing regulations. Id. (citıng Lysaght v. New Jersey, 837 F. Supp. 646 (D.N.J. 1993)). But see Moser v. Frohnmayer, 845 P.2d 1284 (Or. 1992) (holding that the prohibition of automatic dialing announcing devices violates the Oregon State Constitution). The Eighth and Ninth Circuits, the Minnesota Supreme Court, and at least one lower state court have all upheld telemarketing laws. Van Bergen v. Minnesota, 59 F.3d 1541 (8th Cir. 1995); Moser v. FCC, 46 F.3d 970 (9th Cir. 1995); State v. Casino Mktg. Group, Inc., 491 N.W.2d 882 (Minn. 1992); Szefczek v. Hillsborough Beacon, 668 A.2d 1099 (N.J. Super. Ct. Law Div. 1995)

153 See FCC v. Pacıfica Found., 438 U.S. 726, 766 (1978) (Brennan, J., dissentıng)

154 See Nadel, supra note 15, at 101-03 (citing authorttes). 
they are more difficult to block out. Aural communications, therefore, justify more restrictive regulation of free expression than visual communications. ${ }^{155}$ Third, persons frequently receive telephone calls at home. Communications received at home are the most intrusive kind of speech. $^{156}$ More generally, the Court is committed to upholding the principle that while consumers are in the privacy of their homes, they should be able to exercise a high degree of control over the kinds of communications to which they are subjected. ${ }^{157}$

A market-based approach applying to sales calls by for-profit businesses would directly advance the substantial government interests in preventing cost-shifting and protecting consumer privacy. ${ }^{158}$ In Destination Ventures, Ltd. $v$. FCC, ${ }^{159}$ the Ninth Circuit held that a statute prohibiting unsolicited advertising by fax directly advanced the government's substantial interest in preventing the shifting of advertising

155 See Kovacs v. Cooper, 336 U.S. 77, 86-87 (1949) (Reed, J.) (pluralıty opınıon); Deborah L. Hamilton, Note, The First Amendment Status of Commercial Speech, 94 MICH. L. REV. 2352, 2372 $\mathrm{n} .92$ (1996). A ringing telephone is exceptionally difficult to ignore; we are conditioned to answer each phone call. James A. Albert, The Constitutionality of Requiring Telephone Companies To Protect Their Subscribers from Telemarketing Calls, 33 SANTA CLARA L. REV. 51, 52 (1993) (citing MYRON BRENTON, THE PRJVACY INVADERS 176 (1964)), recounts the story of a sulcide jumper who crawled off the ledge of a bulding and back into his apartment in order to answer a ringing phone.

156 See Nadel, supra note 15, at 103. Cox, supra note 64, at 420, notes, "All of the courts.. have held that the telephone is a uniquely invasive technology that allows solicitors to come 'into' the home."

157 For example, in Rowan v. United States Post Office Dept., 397 U.S. 728, 736 (1970), the Court observes, "In today's complex society we are inescapably captive audiences for many purposes, but a sufficient measure of individual autonomy must survive to permit every householder to exercise control over unwanted mail." Later in that same opinion, the majority asserts:

The ancient concept that "a man's home is his castle" into which "not even the king may enter" has lost none of its vitality, and none of the recognized exceptions includes any right to communicate offensively with another. . .

We therefore categorically reject the argument that a vendor has a right under the Constitution or otherwise to send unwanted material into the home of another. If this prohibition operates to impede the flow of even valıd ideas, the answer is that no one has a right to press even "good" ideas on an unwilling recipient. That we are often "captives" outside the sanctuary of the home and subject to objectionable speech and other sound[s] does not mean we must be captives everywhere.

Id. at 737-38. We regard the "home" as a "sanctuary" in part because it is the one place in which we are not "subject to objectionable speech." Id. at 738. See also Pacifica Found., 438 U.S. at 748 ("[I]n the privacy of the home ... the individual's right to be left alone plainly outweighs the First Amendment rights of an intruder." (citing Rowan v. United States Post Office Dept., 397 U.S. 728 (1970))); Florida Bar v. Went For It, Inc., 515 U.S. 618, 624-25 (1995).

158 Courts have recognized that other important government interests may be vindicated by telemarketıng regulations. In Van Bergen v. Minnesota, 59 F.3d 1541, 1554 (8th Cir. 1995), the Eighth Circuit recognized that the government had a significant interest in promoting the efficient conduct of business operations. In State v. Casino Mktg. Group, 491 N.W.2d 882, 888 (Minn. 1992), the Minnesota Supreme Court recognized that the government had a significant interest in preventing fraud, but eventually concluded that the law under review was not tallored narrowly enough to prevent fraud. Cox, supra note 64 , at 420 , discusses the several government interests recognized by courts in telemarketıng cases.

159 46 F.3d 54 (9th Cir. 1995). 
costs onto consumers. ${ }^{160}$ Specifically, the court held that the prohibition was justified because fax advertisements rendered faxes temporarily unavailable for other uses and compelled the recipient to pay for the special paper on which the faxes were printed. Needless to say, the court's rationale that the government had the right to intervene to prevent advertisers from externalizing costs onto consumers mirrors our own rationale for proposing a market-based approach to telemarketing regulation.

The Court has repeatedly held that the government has an important interest in protecting the right of persons not to be made unwilling listeners in their homes. ${ }^{161}$ Over the past decade, a series of state and federal courts have found that telemarketing regulations, such as a law prohibiting the use of automatic dialing machines without live operators and the TCPA provision requiring telemarketers to maintain internal opt-out lists, directly advance the governmental interest in residential privacy. ${ }^{162}$

The fact that a law applying solely to phone solicitations by businesses would fail to regulate some activities-charitable fundraising and polling - that shift costs and invade privacy should not discourage courts from holding that the law directly advances these government interests. Though the direct advancement standard remains ambiguous, ${ }^{163}$

160 In this case, the Oregon District Court found cost-shıfting to be a substantial government Interest and Destination Ventures did not contest this finding before the Ninth Circuit. The Ninth Circuit took note of this chain of events in its majority opinion. Id. at 56-57. The District Court observed that the legislative history of the TCPA identified cost-shifting as a government interest. Destination Ventures v. FCC, 844 F. Supp. 632, 635 (D. Or. 1994). See generally Joshua A. Marcus, Note, Commercial Speech on the Internet: Spam and the First Amendment, 16 CARDOZO ARTS \& ENT. L.j. 245, 295-96 (1998) ("While no court other than the District Court deciding Destination Ventures has addressed whether cost shifting is a substantial government interest, several courts have held that the government has a substantial interest in regulating activities which may result in economic harm.")

161 Frisby v. Schultz, 487 U.S. 474, 487 (1987) (citıng Consol. Edıson Co. v. Pub. Serv. Comm'n, 447 U.S. 530, 542 (1980) and Bolger v. Youngs Drug Products Corp., 463 U.S. 60 (1983)); see also Pacifica Found., 438 U.S. at 748-49 ("[I]n the privacy of the home . . . the individual's right to be left alone plainly outweighs the First Amendment rights of an intruder."). See generally Cary $v$. Brown, 447 U.S. 455, 471 (1980) ("Preserving the sanctity of the home, the one retreat to which men and women can repair to escape from the tribulations of their dally pursuits, is surely an important value. ... The State's interest in protectung the well-being, tranquility, and privacy of the home is certainly of the highest order in a free and civilized society.").

162 See Van Bergen, 59 F.3d at 1554; Moser v. FCC, 46 F.3d 970, 974 (9th Cir. 1995); Casino Mktg., 491 N.W.2d at 888; Szefczek v. Hillborough Beacon, 668 A.2d 1099, 1108 (N.J. Super. Ct. Law Div. 1995).

163 Hamilton, supra note 155, at 2373-74 n.99, summarizes Supreme Court holdings on the direct advancement standard. She writes:

The Court has not indicated exactly what evidence satisfies the directadvancement standard. The Court frequently says regulations that "directly advance" the government's interest meet the standard, while those that provide only "ineffective or remote" support fail the test. The Court has indicated that "studies" could provide the basis for a judgment that a regulation materially advances privacy. In Central Hudson, the Court suggested that the directadvancement requirement was satısfied by a "direct link" between the regulation and the government interest. 
numerous precedents affirm that partial or under-inclusive solutions can satisfy this prong of the commercial speech test. ${ }^{164}$ In Destination Ventures, the defendant argued that a prohibition on fax advertisements failed the commercial speech test because it did not regulate other kinds of unsolicited faxes, such as prank faxes, that also imposed costs on consumers. Noting that advertisements constituted the bulk of unsolicited faxes-just as ordinary sales calls apparently constitute the bulk of phone solicitations - the Ninth Circuit rejected this argument. Meanwhile, the Minnesota Supreme Court upheld a telemarketing law that included a statutory exemption for non-profit organizations. The court remarked that the state is "free to believe that commercial telephone solicitation is a more acute problem than charitable telephone solicitation." 165

There is also a reasonable fit between the extent to which our proposal suppresses speech and the degree to which it prevents costshifting and invasions of privacy. The only restraint a market-based approach places on telemarketers is that it forces them to internalize the costs they had previously "shift[ed]" to consumers. Our proposal is literally no more extensive than necessary to prevent cost-shifting. The same cannot be said about the prohibition on fax advertising at issue in Destination Ventures; nevertheless, the Ninth Circuit held that there was a reasonable fit between the prohibition and the goal of preventing costshifting. Given the lenient manner in which the final prong of the commercial-speech test is applied, courts would also likely hold that there is a reasonable fit between the extent to which our proposal discourages communication and the degree to which it protects residential privacy.

\section{Theoretical Critiques of Privacy Markets}

While we have now shown that our market proposal is workable and would correct the excesses of the current regime, recent works by Cass Sunstein, Margaret Jane Radin and Anita Allen each suggest other grounds for questioning the privacy markets. Sunstein's critique emanates from the viewpoint that too much privacy is dangerous to republican government. Radin's and Allen's criticisms, by contrast, reflect fears that too little privacy is detrimental not merely to democracy but also to personhood. All three scholars nevertheless share an underlying concern about the continued spread of literal and metaphorical markets.

Id. On the basis of these pronouncements, Hamilton concludes that if the government had a substantial interest in reducing the frequency with which some phenomenon occurred, then a policy that achieved a thirty-nine percent decrease in the occurrence of this phenomenon would satisfy the directadvancement standard. Id.

164 For a list of cases supporting this notıon, see Cincınnatı v. Discovery Network, Inc., 507 U.S. 410, 442 (1993) (Rehnquist, J., dissentıng).

165 Casino Mktg., 49l N.W.2d at 890. 


\section{A. Sunstein's Concern with Excessive Filtering}

Cass Sunstein's argument in Republic.com about the undesirable consequences of information filtering suggests an important challenge to our proposal-which in essence is a method of facilitating household filtering of telemarketing calls. Sunstein argues that technologies that enable consumers to filter with increasing precision the content on the Web, television and radio and in newspapers and magazines will produce social polarization and fragmentation. ${ }^{166}$ Polarization would occur if large numbers of individuals used these technologies to exclude content featuring viewpoints inconsistent with their own and discussing subjects in which they did not have a prior interest. Because they would interact almost exclusively with like-minded people, such individuals would develop more extreme versions of their existing viewpoints and would focus on existing hobbies to the exclusion of new interests. This phenomenon would make it harder for people on opposite sides of an issue to relate- because there would be a larger gulf between them and because they would have less in common in other facets of their lives. ${ }^{167}$

Though Sunstein does not discuss how his thesis applies to direct marketing, one can extrapolate a likely answer. Sunstein is concerned that in the future, people will not voluntarily access (or "pull") certain kinds of vital information. He would prefer that individuals be exposed to at least some of this information, whether or not they would so choose in their capacity as consumers. ${ }^{168}$ One imagines therefore that Sunstein would prefer a situation in which speakers can "push" this information at consumers to one in which consumers are not exposed to it at all. ${ }^{169}$ Indeed, he might argue that the more selective consumers become about what they pull, the more the state should seek to protect speakers' ability to "push" information using spam and other direct marketing techniques.

Another dimension of Sunstein's philosophy that suggests he would be critical of our plan to commodify direct marketers' access to individuals is his approach to First Amendment jurisprudence. Sunstein writes that there are two camps of First Amendment scholars: persons concerned with perfectly satisfying consumers' demands for customized menus of information goods and persons concerned with preserving a healthy

166 CASS SUNSTEN, REPUBLIC.COM 8-9, 16, 51-80 (2000).

167 See id. at 51-80, 91-99.

168 See, e.g., id. at 167.

169 One facet of Sunstenn's argument that underscores his sympathy for parties that push speech at members of the public is his affection for traditional public forums such as parks and street comers. Sunstein celebrates the fact that the public forum doctrine allows speakers in parks and on corners to subject members of the public to orations about whatever the speakers please. See, e.g., id. at 12,15 . Needless to say, soapboxes are the most primitıve "push technology." 
republic populated by public-spirited and well-informed citizens. ${ }^{170}$ Our proposal has an unabashed consumer orientation. In particular, our observation that the government could empower consumers to infinitely differentiate the prices they charged depending on time, subject matter and other factors calls to mind the very system that Sunstein himself rejects. ${ }^{171}$ He vividly envisions a world where filtering and pull technologies become so diabolical that instead of purchasing USA Today, consumers would persistently opt for a radically solipsistic Me Today. ${ }^{172}$

While we share some of Sunstein's concerns about the "Brave New World" of perfected consumer filtering, at the end of the day, we think that allowing consumers to reclaim control of their market privacy-that is, their right to be free from unwanted commercial solicitations-actually complements Sunstein's project of maintaining citizens' openness to noncommercial solicitations. Sunstein himself repeatedly acknowledges that some filtering is necessary to prevent information overload. ${ }^{173}$ As someone who believes that communications policy should emphasize people's role as citizens rather than as consumers, ${ }^{174}$ Sunstein regards ordinary direct marketing solicitations as lower priority speech. He might therefore endorse a regime that allows consumers to restrict telemarketing solicitations, so that people would have more time and attention to devote to higher priority communications. The need to allow consumer filtering with regard to telemarketing and spam emails is particularly acute because these methods of communication entail very small marginal costs (of push) and hence are not self-limiting in the ways that the soapbox is.

Finally, telemarketing solicitations differ from the exchanges that Sunstein regards as paradigmatic manifestations of the social function of speech since they occur in private spaces. As Sunstein repeatedly indicates, the inspiration for his analysis of the social functions of speech is the exchanges that take place in traditional public forums such as parks and street corners. ${ }^{175} \mathrm{He}$ extols these forums because they give rise to

170 See id. at 141-66.

171 Sunstein describes a hypothetical future in which consumers can filter information using an essentially endless range of criteria. See id. at 3-5. Further, he first identifies the dystopic elements of this vision, $i d$. at 8-10.

172 Sunstein creates the impression that a legal thınker's views about the primacy of an individual's role as consumer or his role as citizen is consistent for all First Amendment issuesimplyıng, in effect, that for First Amendment purposes, one is either a consumer advocate or a republican. See, e.g., id. at 46-48 (portrayıng a dichotomy between the visions of the First Amendment championed by Justices Holmes and Brandeis). We regard as coherent the view that different roles should have primacy for different First Amendment issues. Regulations targeted chiefly at direct marketing, for example, might invite a scholar to treat individuals primanly as consumers, whereas a law aimed at stump speeches could impel the same person to consider individuals as citizens.

173 See id. at $56-57$.

174 See id. at $22,105$.

175 See, e.g., id. at 12, 15, 28, 196, 201. See also Carl S. Kaplan, Law Professor Sees Hazard in Personalized News, N.Y. TIMES ON THE WEB, April 13, 2001, at 
"[u]nplanned and unchosen encounters."176 But one of the cherished features of domestic life is the fact that individuals can avoid unwanted encounters. Preserving a private sanctuary where citizens have the right to be free from entreaties may actually make them more receptive when they venture out from their homes. Privacy is a low priority in public spaces and an exceedingly high priority in homes.

There is the risk that consumers who are compensated for commercial solicitations will become less receptive to uncompensated non-commercial solicitations. Residents will have more time to take non-profit solicitations, but will more acutely feel the opportunity cost of speaking to a campaign worker instead of a carpet cleaner. But we are encouraged by the fact that most people used to participate in Gallup polls before overfishing by telemarketers became such a problem. Recent empirical research suggests that citizens who see their altruistic acts as having a market value may become more charitable. ${ }^{177}$ While this issue is not free from doubt, our exemption of non-commercial speech from consumer pricing goes a very long way toward blunting Sunstein's core concern.

\section{B. Radin's Concern with Commodification}

In Contested Commodities, Margaret Jane Radin argues that societies should not tolerate markets in certain kinds of goods and services. She distinguishes between fungible property, which is interchangeable with like items and money, and personal property, which is not. ${ }^{178}$ Radin contends, "Since personal property is connected with the self, morally justifiably, in a constitutive way, to disconnect it from the person (from the self) harms or destroys the self." ${ }^{\prime 179}$ For Radin, it would be undesirable to commodify the right to be left alone by direct marketers if this right were a type of personal property. ${ }^{180}$

http://www.nytımes.com/2001/4/13/13CYBERLAW.html (reporting Professor Sunstein's observation that Republic.com is in part an ode to city living).

176 SUNSTEIN, supra note 166 , at 35.

177 For example, Strahılevitz found that when the city of San Diego began selling individuals rights to use high occupancy vehicle lanes on the highway, the willingness of others to car pool increased. Lior Jacob Strahılevitz, How Changes in Property Regimes Influence Social Norms: Commodifying California's Carpool Lanes, 75 IND. L. J. 1231, 1254-56 (2000).

178 Radin introduced the distınction between fungible property and personal property in Margaret Radin, Property and Personhood, in Reinterpreting Property 37 (1993).

179 See id.

180 Radin offers a variety of other arguments against commodification, including the negative consequences of market rhetoric and the likelihood that commodification will engender other forms of objectification such as subordination. A market approach to the externalities engendered by direct marketing seems unlıkely to cause what Radin calls "unjustıfied dominance . . by one person or group." Id. At most, one could argue that because wealther consumers would probably earn more on average than poorer consumers, our system would produce maldistribution of wealth-and maldistribution of wealth enables the rich to dominate the poor. But Radin herself is ambivalent about the link between maldistribution of wealth and wrongful subordınation. See id. at 158. And the 
The right to be left alone by telemarketers currently is not a species of personal property because most Americans lack the right to prevent such intrusions. Radin states that commodification is undesirable when it facilitates the alienation of property that has become bound up with the self. $^{181}$ But property cannot become bound up with the self unless the person has actually possessed or enjoyed it for a period of time. As we have explained at greater length in Part III, the basic default rule in the United States is that telemarketers can solicit consumers. ${ }^{182}$ Most states, moreover, do not afford consumers the right to opt-out of all future telephone solicitations. Since the large majority of Americans have never enjoyed a property interest in the relevant dimension of physical privacy, it cannot have become bound up with their personhood and thus cannot be personal property. ${ }^{183}$

The status quo aside, it is unclear that the right to be left alone by telemarketers could ever constitute personal property. Radin draws upon a variety of theories to develop a catalogue of items connected with personhood ${ }^{184}$-including: "Separateness: 'Being able to live one's own life and nobody else's; being able to live one's own life in one's very own surroundings and context.' To flourish, humans need at least some finite amount of certain pre-requisites for personhood (such as separateness)." Under Radin's theory, society should presumably only prohibit the commodification of things the sale of which would plunge us below the threshold amount of these prerequisites. Radin would only prohibit the sale of our right to be left alone by direct marketers if as a consequence of these transactions we did not have enough solitude to flourish as human beings. Even supposing that separateness referred solely to the dimension of physical privacy implicated by our proposal, it seems questionable whether the commodification of direct marketing would disturb individuals' seclusion to such a degree that their context and surroundings would no longer be their own.

applıcation of market rhetorıc to self-conceptions of prıvacy is unlıkely to undermine indıvıduals' conceptions of their self-worth. As a theoretical matter, a consumer who charged telemarketers a moderate price might regard a lack of calls as a blow to his self-worth-as an indication that businesses did not value access to him. But though it is possible, we are skeptical that this phenomenon will be widespread.

181 See, e.g., id. at 58.

182 Technically, residents have a market inalienable right to be left alone between the hours of 9 p.m. and $8 \mathrm{a} . \mathrm{m}$. and the right upon request not to be called back by individual telemarketers. See supra note 8

183 Radin's philosophical outlook suggests that she would be receptive to an argument premised on the American status quo. Radin describes herself as a "pragmatıst" with a preference for "stickıng fairly close to the detalls of context and not engaging in a search for a grand theory." RADIN, supra note 178 , at $x i 1,63$.

184 See id. at 63-72.

185 Id. at x1-xiv (citing Martha C. Nussbaum, Human Functioning and Social Justice-In Defense of Aristotelian Essentialism, 20 POL. THEORY 202, 222 (1992)). 
The ambiguous character of "[s]eparateness" and the fact that most Americans have little right to exclude telemarketing solicitations mean that the right to be left alone is unlikely to become bound up with individuals' personhood. But even if the right to be left alone by direct marketers had become connected with the self, then our scheme would nevertheless diminish the amount of harm being done to personhood. Radin contends that the self is harmed or destroyed when personal property is "disconnect[ed]" from its prior owner. Market transactions are not the only means by which to "disconnect" something. A party can also disconnect an item by taking it without the prior owner's permission. As we have already noted, the United States' legal regime allows direct marketers to solicit most consumers virtually at will. So to the extent that these consumers' right to be left alone has become connected with their personhood, it is also being disconnected on a more-or-less daily basis. Far from making matters worse, our approach would protect personhood by empowering all individuals to reduce or eliminate unsolicited solicitations. In today's world, the only thing worse than commodifying individuals' right to privacy is to leave the right uncommodified and in the control of the telemarketers themselves. Compared with the status quo, allowing consumers to commodify their privacy is likely to be productive of human flourishing.

\section{Allen's Concern with Uncoerced Privacy}

In Coercing Privacy, ${ }^{186}$ Anita L. Allen wonders whether government should impose mandatory rules that would force individuals to have more privacy than many would choose for themselves. Accordingly, government might need to limit individuals' ability to waive some types of privacy. ${ }^{187}$ Allen argues that privacy is a prerequisite for moral autonomy, and moral autonomy is a prerequisite for liberal democratic society, so the government must protect privacy to save liberal democratic society. ${ }^{188}$

Note the distance between Sunstein and Allen: Sunstein argues that we must restrict individuals' ability to be left alone in order to make them better citizens; Allen argues that we must restrict individuals' ability to waive (or sell) their rights to be left alone to make them better citizens.

Our proposal should clearly not be a concern for Allen relative to the present regime in which direct marketers can invade household privacy at will. But Allen might argue that a "don't-call" statute with its all or nothing choice, or an outright ban of telemarketing calls would be superior

186 Allen, supra note 73. Anita L. Allen, Lying to Protect Privacy, 44 VILL. L. REV. 161, 161

n.1 (1999), lists many of Professor Allen's artıcles about privacy.

187 Allen, supra note 73 , at 752.

188 See id. at 740.

132 
because it would provide a more thorough guarantee that individuals' attentions would not be diverted from their moral and democratic deliberative duties. While Allen's argument is intriguing, she herself only raises the idea of "coercing privacy" as a possibility. ${ }^{189}$ And as an empirical matter, prohibiting the alienation of household privacy is unlikely to secure superior moral or democratic deliberation. Individuals routinely alienate other aspects of their time (i.e., their job), prohibiting alienation of telemarketing time is unlikely to assure that they will think about moral issues (as opposed to Monday Night Football) and choosing to alienate a portion of their household time may actually give them more resources to deliberate at other times.

But Allen also argues that privacy markets that provide "opportunities to earn money and celebrity by giving up privacy voluntarily"190 may erode the taste for privacy. In other words, markets construct tastes as well as respond to tastes. ${ }^{191}$ Allen believes that preserving consumers' taste for privacy is essential not only because privacy is a prerequisite for liberal democracy but also because privacy has numerous other instrumental benefits. $^{192}$

Whether commodification diminishes individuals' valuations of an item depends, however, upon the status quo the privacy market replaces. Most debates about commodification are about whether ostensibly priceless items should receive monetary valuations. To adopt Professor Radin's language, we ask whether it injures a baby's personhood to say that the child is worth a fixed dollar amount. ${ }^{193}$ Whatever regime we adopt to regulate babies or sex or body parts, we express our view that these things are enormously important by imposing criminal as well as civil penalties on parties that take them from their rightful owner or guardian without that party's consent. By contrast, direct marketers do not need an individual's consent to invade his physical privacy. Commodification, therefore, would mean a switch from a regime that values physical privacy at zero (since marketers can consumer it at will and without cost) to one in which physical privacy has positive value. Telemarketing suggests a second meaning to the Mastercard term, "priceless." The transition from government-imposed pricelessness to market valuation may cause people to value the item less highly. But the switch from government-imposed

189 Id

190 Allen, supra note 73 , at 731.

191 See id. at 735. Allen also complains that in contemporary society "numerous little consensual and nonconsensual privacy losses, too trivial to protest individually, aggregate into a large privacy loss that is a detriment to the liberal way of life." Id. at 740,756 .

192 See id. at $737-741$.

193 See supra note 180 . 
worthlessness to market valuation should cause people to value it more highly. ${ }^{194}$

The view that privacy markets would cause consumers to become accustomed to more frequent intrusions makes little sense since our approach should reduce the volume of most if not all kinds of solicitations. Our regime should reduce the overall number of solicitations by increasing the cost to direct marketers of contacting a consumer. ${ }^{195}$ The only class of people for whom solicitations may increase are those who currently opt for more extreme forms of interdiction-such as registering for the "don'tcall" lists. But if these people, once given the opportunity, prefer to grant limited calling rights in return for compensation, we fail to see a compelling reason in terms of either human flourishing or external impacts on citizenship to warrant overturning their decisions.

While a variety of concerns have been raised about market-oriented attempts to "price privacy," our proposal to grant households an alienable right to be free from commercial solicitations is likely to promote diverse conceptions of the good. Allowing people to protect themselves from commercial speech is likely to make them more open to non-commercial solicitations. And allowing citizens to commodify their privacy is far better than granting telemarketers the right to invade their privacy for nothing. Radin and Allen might respond that we should just abolish commercial telemarketing altogether, but that level of coercion is likely inimical to core free speech values and has not to date been seriously proposed.

194 Given Allen's view that privacy supplies numerous instrumental benefits, see id., she should also appreciate the fact that commodification of direct marketing would make consumers think about privacy-related issues. By invitıng consumers to set a price for unsolicited solicitations, our approach impels them to reflect about how much they value their solitude. More basically, it reminds them that they have a right to be left alone-a right that they can choose whether and at what price to alienate.

Neither the status quo nor a mandatory ban on solicitations would engage consumers in a comparable manner. Since consumers cannot adjust the default settıng, they have no reason to consider how much they value being left alone. These regimes are not only non-interactive but also largely invisible. Under a mandatory ban, for example, there would be no impetus for consumers to become cognizant of the fact that they enjoyed a right to physical privacy. The concept of solitude becomes meaningful when and if a person is subject to intrusions.

195 The only type of direct marketing that might actually become more prevalent is spam, since a market approach would probably expand the range of companies that advertised by email even as it constricted the flow of emails sent by exısting spammers. A market approach to spam would probably increase the number of companies that advertise by emall since it would change the view that spam violates online etiquette. This view discourages companies that enjoy strong reputations and significant consumer goodwill from sending spam.

A market approach would diminish the number of emails sent by companies that already use spam since the added cost would force them to target their advertısing more narrowly-at the subset of consumers that is most likely to be interested in their particular goods or services 
Marketing Privacy

\section{Applications to Junk Mail and Spam}

The same types of disclosure and compensation proposals that we have argued would ameliorate the problems associated with telemarketing could also be used to improve other conduits of direct marketing-such as junk mail and spam.

As discussed above, standardized initial disclosure would greatly facilitate household filtering of these media. If direct mailers were required to place a uniform symbol in the lower-left hand comer of an envelope, recipients could much more easily discard unopened junk mail without worrying whether the letter contained a tax form or check. And if spammers were obliged to place a uniform string in the subject line, existing email software could easily discard unwanted spam or transfer it to a bulk mail folder. ${ }^{196}$ The low cost and effective filtering allowed by this simple disclosure requirement would provide most of the benefits of "don't-email" registries. ${ }^{197}$ At the same time, it would give consumers the option of creating more nuanced filters than the all-or-nothing registries allow. In the shadow of the disclosure requirement, direct marketers are likely to stop hoodwinking households with non-solicitation solicitations (such as "important tax information enclosed") and instead will provide more pertinent information to pique the consumers' legitimate interest. Mail recipients might decide not to throw out all unsolicited mailchoosing, at least, to skim the contents of mailings that describe enticing offers on the envelope. ${ }^{198}$

Uniform standardized disclosure is already required on some junk mail-namely, junk mail from lawyers. Model Rule 7.3(c) mandates as part of a "labeling requirement" that every letter "from a lawyer soliciting professional employment from a prospective client known to be in need of legal services ... shall include the words 'Advertising Material' on the outside envelope ....",199

But as with telemarketing, we can do better than mandatory disclosure. There are parallel benefits to creating market-based regimes that allow recipients to "name the price" that they wish to be paid for receiving pieces of direct mail or spam. Since traditional mail and email can be read at different times, such pricing would not have to be as

196 Ten states have laws regulatıng the labelıng of unsolicited emall advertisements. Seven states-Califomia, Colorado, Florida, Nevada, Pennsylvania, Tennessee and Wisconsin-require spammers to insert a uniform string of characters (such as "ADV:") in the subject line. Three statesIllınoıs, Washington and West Vırginı--prohibıt false or mısleading labelıng See Sorkın, supra note 68 .

197 Germany apparently has allowed households to opt out of junk mail by puttıng a certain sticker on their mailbox.

198 Spam recipients might decide to retan unsolicited commercial emails that contain certain key words related to the recipients' interests.

199 MODEL RULES OF PROF'L CONDUCT R. 7.3(c) (2001). 
intricately time-contingent as telemarketing compensation. ${ }^{200}$ And as with our preferred telemarketing system, the monetary transfers could be accomplished by the recipient's local telephone carrier. Junk mailers would be required to use special postal meters that had an "outgoing 1900 " feature so that mailings to particular addresses would automatically trigger payments to the phone company. Unsolicited emails could work through a similar system or with some type of pay-pal software. Indeed, Larry Lessig and others have already suggested a similar system for compensating spam recipients-but usually with the amount set by the marketer or by the government. ${ }^{201}$ However, because spam can (and increasingly does) originate from abroad, it is increasingly difficult for a U.S. agency to effectively sanction some spammers who willfully violate a requirement to compensate. Yet even here there are ideas to ensure compliance without government involvement. ${ }^{202}$

While the aggregate harm of spam's externalized costs is probably at the moment less than that of telemarketing, spam is distinctive for imposing zero marginal cost on the telemarketer. Telemarketing and junk mail are at some point self-limiting because it costs something to send a package or to pay someone to place a call. But currently there is virtually no limit to the amount of spam that could be sent via the Internet. In fact, the purity of the market failure associated with spam-the fact that almost all of the marketing costs are externalized-may have provoked our insights into telemarketing. Our market approach to telemarketing has been technologically feasible for many years; it requires nothing more complicated than the software that gave us 1-900 numbers. But the Internet has underscored not just the value of people's attention (aka their "eyeballs" and "eardrums"), but the possibility of compensating them for

200 The temporal disconnect between sending and receipt of spam and junkmail increases the possibility that compensated marketing materials will not be read. But this is an endemic problem of all advertisements, which marketers can mitigate by producing more interesting pitches. See supra Part Il.A. Marketers, for example, could always include a lottery ticket for someone who responds.

201 See, e.g., ESTHER DYSON, RELEASE 2.1: A DESIGN FOR LIVING IN THE DIGITAL AGE $172-$ 201 (1998); Lawrence Lessıg \& Paul Resnick, Zoning Speech on the Internet: A Legal and Technical Model, 98 MICH. L. REv. 395, 428-29 (1999); Petty, supra note 4, at 46.

202 Barry Nalebuff, a professor at Yale's School of Management, has suggested to us a system in which a three-part norm develops to solve the problem of uncompensated spam. The first part of the norm is that all emall senders would include a paypal certificate that offers to pay 30 cents. The second part to this norm is that recipient software would be constructed to block any email that did not have the requisite paypal certıficate attached. At this point, you are probably thinking that this is a terrible idea that would force your friends to pay for casual conversation, but the key of Nalebuff's idea is the third part of the norm. Recipients would not cash the paypal certificate unless it came from a spammer. Voila. The spammers would either be blocked for failing to attach a valid certificate or they would be put out of business by all the annoyed masses who clicked on their 30 cent certificates. Vanquish.com has independently developed and begun implementıng just this product. See also Kirı Blakeley, E-maily Dickenspam, FORBES, Sept. 16, 2002 (detailıng how Habeas.com has a system for tagging emails with copyrighted halku, which is licensed for free to individuals, but is a massive copyright violation if used by spammers). 
their time. While we have centered our arguments on the most important direct marketing abuse, we might just as easily have started our narrative with junk mail or spam-where the benefits of standardized initial disclosure and consumer-driven compensation are to our minds abundantly clear.

\section{Conclusion}

This Article argues for the creations of a market in the right to be left alone by telemarketers (and spammers and junk mailers). All types of direct marketing externalize costs onto consumers; all are amenable to the same basic solution. Rather than giving households the all-or-nothing choice of the "don't-call" statutes, we should allow households to condition access to their homes on payment of some minimum requisite compensation. Telemarketers (and other direct marketers) should be required to disclose the nature of the communication at the outset in a standardized manner. Giving households more information and more choice obviously increases consumer welfare. But we have also shown that the requirements of disclosure and compensation may also increase the freedom of telemarketers to reach consumers who would otherwise bury their proverbial heads in the sand.

The states and the Federal Trade Commission ("FTC") can do better than the current rush to "don't-call" registries. At a minimum, the FTC should be careful not to preempt the freedom of states to adopt a marketbased compensation system. Indeed, care should be taken to allow the private telephone companies to provide at least a voluntary "outgoing 1900" system, under which telemarketers would have the option of competing for consumer attention on the basis of offered compensation.

But the time is ripe for us to act nationally. Instead of groaning at the thought of telemarketing calls and embracing consumer interdiction as the only possible policy, we should think of compensated calls as a huge opportunity. If we jettison the unnecessary prohibitions against prerecorded calls-and thereby intentionally lower the marginal cost of speaking-there is a real possibility that the telephone could become a major conduit for advertising. Have five minutes to spare waiting for your train? Why not turn on your cell phone and make some cool hard cash? Instead of asking the rhetorical question of how much we would be willing to pay to avoid these unsolicited solicitations, we should be able to ask ourselves the consequential question, "How much do we want to be paid?" 
HeinOnline -- 20 Yale J. on Reg. 1382003 